\title{
9. THE FOSSIL DISTRIBUTION OF COCCOLITHOPHORE GENUS GEPHYROCAPSA KAMPTNER AND RELATED PLIO-PLEISTOCENE CHRONOSTRATIGRAPHIC PROBLEMS ${ }^{1}$
}

\author{
Domenico Rio, Institute of Geology of the University of Parma, Parma, Italy
}

\begin{abstract}
In this chapter I report the study by light microscope of the distributions of the Gephyrocapsa complex in sections from widely separated oceanic areas and from the Mediterranean region. Even using an informal non-Linnaean taxonomic approach based on size, I was able to trace substantial successive morphologic changes, which allow correlations to be made between Mediterranean reference sections and oceanic records.

In particular, I found that small representatives of the genus appear as early as the top of lower Pliocene, near the top of the NN15 Zone of Martini's Standard Zonation. After a short bloom near the Tabianian/Piacenzian boundary, recorded in all the sections investigated in different water masses, Gephyrocapsae became scarce or absent, being most abundant in terrigenous and hemipelagic sections. Sometimes they were common in the nannoflora assemblage in the uppermost Pliocene, becoming the dominant forms in the Pleistocene.

During the upper Pliocene-lower Pleistocene, they underwent marked morphologic changes, which could be observed by light microscopy. A trend toward larger size in the lower Pleistocene is evident and is stratigraphically useful. Forms larger than $6 \mu \mathrm{m}$ seem to be restricted to lower Pleistocene.

Another important morphologic change concerns the alignment of the diagonal bar with the short axis in the placolith. In normal-sized forms, this feature is reached only in the mid-Pleistocene, after Gartner's "small Gephyrocapsae Zone."

The paleomagnetic stratigraphy of DSDP Holes 502B and 503B allows the calibration of appearance time for these different morphologic groups. Small Gephyrocapsae together with P. lacunosa appear in the upper part of the Gilbert (near 3.5-3.6 Ma), which is the most probable age for the Tabianian/Piacenzian boundary.

Normal-sized Gephyrocapsae (labeled here G. oceanica s. 1.) appear at the top of the Olduvai Event. In the Italian sections, including the Vrica section, a stratotype of the Plio/Pleistocene boundary, this event is recorded just above the base of the Pleistocene. An approximate age of 1.6-1.7 Ma is therefore estimated for the Plio/Pleistocene boundary. This is in agreement with the recent finding of Globorotalia truncatulinoides truncatulinoides in the Mediterranean Pliocene (Sprovieri et al., in press; Rio et al., in preparation).

On the basis of the Gephyrocapsa evolution, I assigned ages to the Mediterranean lower Pleistocene marine stages (ages are approximate): Santernian, 1.6-1.7 to 1.3 Ma; Emilian, 1.3-1.2 Ma. The Sicilian base is at about 1.1-1.2 Ma, whereas the top has not yet been defined; it should occur, however, shortly after the end of the Jaramillo.
\end{abstract}

\section{INTRODUCTION}

One of the major goals of stratigraphy is to establish an International Geochronologic Scale. It is supposed to provide the standard time framework for unravelling the geologic history of Earth and a worldwide basis for the sake of intra- and interdisciplinary communication and understanding in the scientific community. In order to establish such a scale, different steps and procedures are required; these have been extensively discussed in the recently published International Stratigraphic Guide (Hedberg, 1976) and widely accepted.

A basic principle stated by the Guide is the stratotype concept that the only and best objective and permanently stable basis for defining a point and/or interval in geologic time is an established point and/or interval in a sequence of continuously deposited rock strata (Hedberg, 1978).

The chronostratigraphic units of Pliocene and Pleistocene in the International Geochronologic Scale have been defined in Italy, where they were first introduced. The practical value and utility of these units depend on the extent and accuracy with which the interval or point

\footnotetext{
${ }^{1}$ Prell, W. L., Gardner, J. V., et al., Init. Repts. DSDP, 68: Washington (U.S. Govt. Printing Office).
}

in time, defined in the stratotype sections, can be identified in the extra-Mediterranean record.

The aim of time correlating stratotypes with other geologic records may be achieved by different methods (Hedberg, 1978). Among these, planktonic-microfossilbased biostratigraphy is the most currently used, since, because of the irreversible course of organic evolution, it provides time indicative nonrepetitive events.

Planktonic foraminifers and calcareous nannofossils are the only microfossils present in the Mediterranean geologic record in sufficient quantity to be used for long-distance correlations. It is well known that during the late Neogene and Pleistocene, Mediterranean planktonic foraminiferal fauna shows a strikingly different makeup than in the oceans (Thunell, 1979). When planktonic foraminifers were the only available fossils, this always complicated time correlations and, consequently, the application of the Mediterranean-based stages/ages of Pliocene and Pleistocene, until some years ago. It is sufficient to recall here the endless arguments concerning the Plio/Pleistocene boundary (see Haq et al., 1977, and Pelosio et al., 1980), as a consequence of the different distribution of Globorotalia truncatulinoides in Mediterranean and oceanic records.

With the development of global stratigraphic schemes based on calcareous nannofossils, we could finally hope 
to solve the problem by means of phytoplankton, less affected than foraminifers by provincialism.

Actually, although all the important nannofossil index species occur in the Mediterranean, some important groups like discoasters and ceratoliths are exceedingly scarce, especially in the Mediterranean onland record, where the stratotypes are defined. Furthermore, in most Italian onland sections, a strong reworking makes the evaluation of the last appearance datum (LAD) of some species uncertain and not very reliable. Not surprisingly, therefore, the LADs of important index species, like that of Discoaster brouweri in the proposed Plio/Pleistocene boundary stratotype of Le Castella (cf. Smith, 1969 , and Bandy and Wilcoxon, 1970), are highly inconsistent in the Italian reference sections.

Both reworking and ecological control have forced paleontologists (Rio, 1974; Gartner, 1977a; Haq et al., 1977 ) to rely upon the first appearance datum (FAD) of forms like Pseudoemiliania lacunosa and Gephyrocapsae, which are normally neglected in the biostratigraphic subdivision of the extra-Mediterranean regions. In particular, the Gephyrocapsa complex, owing to a fairly high environmental tolerance, occurs in great abundance in Italian sections, where other commonly used index species, like discoasters, are scarce or absent. Furthermore, since they underwent morphologic evolution during the critical late Pliocene-Pleistocene interval, $\mathrm{Ge}$ phyrocapsae represent the most promising taxa for biostratigraphic subdivisions and correlations on the basis of FAD datums, thus overcoming the uncertainties introduced by reworking.

These potentially useful taxa, however, cannot be adequately exploited at the moment, because discrepancies in taxonomy and nomenclature make it difficult to use the data obtained by different authors in extra-Mediterranean sequences.

In* order to overcome this difficulty, I decided to compare the distributions of Gephyrocapsae in sections from widely separated oceanic areas with those of the Mediterranean region, using the same taxonomic approach. In this chapter, I also discuss evolutionary trends within the Gephyrocapsa genus and the bearing of the data on the definition and age of the Plio/Pleistocene boundary and on the chronostratigraphic classification of the lower Pleistocene.

\section{GEPHYROCAPSA COMPLEX: PREVIOUS WORK AND TAXONOMY}

This group of placoliths, ascribed by Perch-Nielsen (1971) to the Prinsiaceae family and by Hay (1977) to the Gephyrocapsaceae family, poses serious taxonomic and nomenclature problems, starting with the definition of the genus. According to most authors, the genus is restricted to placoliths, characterized by a bridge or a diagonal bar in the central area (e.g., Gartner, 1977b; Raffi and Rio, 1979; Haq et al., 1977). Others (e.g., Bukry, 1973b; Pirini Radrizzani and Valleri, 1977) consider the rim structure, form, and crystallography as primary characteristics and consequently also ascribe to this genus other small coccoliths with the same general structure but lacking the central diagonal bar.
In this chapter I follow the majority of researchers and consider as belonging to the genus only placoliths (generally $2 \mu \mathrm{m}$ to $8 \mu \mathrm{m}$ in size) characterized by a bright distal shield and a bright diagonal bar in the central area of the light microscope. Accordingly, the species Gephyrocapsa doronicoides (Black and Barnes) (Bukry, 1973b), Gephyrocapsa producta (Kamptner) (Bukry, 1973b), and Gephyrocapsa reticulata Nishida, 1971, which lack the diagonal bar, are not assigned to the genus.

Taxonomic and nomenclature problems are much more complicated at the species circumscription level, especially for light microscope users. They are due either to the small size, so that many species are characterized by features barely recognizable by light microscopy, or to different classification criteria. Among the small species difficult to identify confidently with the light microscope, are Gephyrocapsa aperta Kamptner, 1963; G. ericsonii McIntyre and Bé, 1967; G. protohuxleyi McIntyre, 1970; G. mediterranea Pirini Radrizzani and Valleri, 1977; G. florencia Lohman and Ellis, 1981; G. kamptneri Deflandre and Fert, 1954; and G. crassipons Okada and McIntyre, 1977.

For all these species as well as for others not described, Gartner (1977b) proposed that the label "small Gephyrocapsae" be adopted by light microscope users. Indeed, at the moment this seems the most realistic possibility in practical biostratigraphy, although small $\mathrm{Ge}$ phyrocapsae are highly variable. Combined light and electron microscope studies, like those carried out by Proto Decima and Masotti (in press), may in the future allow us to distinguish different species among them even by light microscopy.

In light microscopy studies and, more generally, for biostratigraphic purposes, two species are commonly cited: G. oceanica Kamptner, 1943, and G. caribbeanica Boudreaux and Hay, 1967 (in Hay et al., 1967). Both present distinct problems (see Gartner, 1972, 1977b).

G. oceanica indicates, according to all researchers, a Pleistocene age, but the criteria used to identify it, either by light or electron microscopy, are rarely specified and may have varied from one observer to the other. As a matter of fact, the earliest appearance of this species has been inconsistently placed on the time scale: Bukry (1975) locates it at $0.9 \mathrm{Ma}$; Gartner (1977b), between 1.65 and 1.51 Ma; and Haq et al. (1977), at a mean age of 1.57 $\mathrm{Ma}$.

The literature itself reveals contradictions concerning, for instance, the orientation of the diagonal bar, which is variable according to Gartner (1977b) and Bukry (1973b) and according to Hay and Beaudry (1973) is at a less than $20^{\circ}$ angle with the short axis.

Furthermore, according to Kamptner's original description (1943) as well as to other important citations (see Gartner, 1972), the minimum size of this species is $2.4 \mu \mathrm{m}$. It seems evident that Gephyrocapsa oceanica, because it is less than $3 \mu \mathrm{m}$ and thus barely recognizable in the light microscope, will be clustered within the "'small Gephyrocapsa group"' by light microscope users, causing serious errors when range charts obtained by electron and by light microscope are compared.

G. caribbeanica was described by electron microscope by Boudreaux and Hay (in Hay et al., 1967), who 
rely heavily for species recognition on the number of shield elements, orientation and structure of the bridge, and the central area. All these features are difficult to identify by light microscope and, not surprisingly, have not always been used as criteria by investigators for recognizing this species (Gartner, 1972, 1977b). Looking at the literature, one gains the impression that many authors use this species label to include all Gephyrocapsa forms that cannot be identified as $G$. oceanica (see Gartner, 1977a).

Besides $G$. oceanica and $G$. caribbeanica, two other species are often recorded in light microscope studies: G. omega and G. lumina, introduced by Bukry (1973b). They can be distinguished by light microscope, but because they are gradational forms of $G$. oceanica, which occur generally in the population, they are considered variants of G. oceanica Kamptner by Gartner (1977b).

\section{OBSERVATIONAL TECHNIQUE AND TAXONOMIC APPROACH}

In undertaking this study, a basic choice had to be made on which observational technique to use: electron or light microscope. In spite of the small size of the Gephyrocapsa group, I decided to use the light microscope, which for ease of preparation, speed of detection and identification, and availability to most workers under any working condition has become the standard technique in nannofossil paleontology applied to stratigraphy. Obviously, this technique has serious drawbacks for the taxonomic approach. In fact, since light microscope resolution is limited to about $1.5 \mu \mathrm{m}$, systematic criteria generally used for species identification (number of elements and cycles, thickness, structure, and orientation of the diagonal bar) are meaningless to a light microscope user.

Because of these drawbacks I disregarded current classifications and adopted for the range charts a simple, informal, non-Linnaean classification based solely on characteristics easily recognizable by light microscope. Size is the feature easiest to follow in the light microscope and has the advantage of leaving little room for subjectivity. Accordingly, and mainly on the basis of this single feature, I subdivided the Gephyrocapsa complex into, (1) small Gephyrocapsae, lumping all forms less than $3.5 \mu \mathrm{m}$ in size (Plate 1, Figs. 1-8, 10); (2) Gephyrocapsa oceanica s.1., lumping all forms between 3.5 and $5.5 \mu \mathrm{m}$, with a distinct and open central area (Plate 1, Figs. 9, 11-16; Plate 2, Figs. 1-3; Plate 3, Figs. 1-10); and (3) large Gephyrocapsae, lumping all forms $\geq 6 \mu$ m (Plate 2, Figs. 4-12).

Gephyrocapsa forms 3.5-5.5 $\mu \mathrm{m}$, with a small, closed central area often difficult to recognize, are considered to belong to $G$. caribbeanica s.1.; their distribution has not been studied in detail.

\section{SCOPE AND MATERIAL}

The aim of this chapter is to investigate whether the Gephyrocapsa complex can be used for the biostratigraphic classification of the marine geologic record and for age correlations in the Pliocene-Pleistocene interval.
For this purpose, I observed and critically compared the distribution of the Gephyrocapsa complex in Mediterranean sections with that in widely separated oceanic areas (Atlantic, Pacific, Caribbean [Fig. 1]). The sequences are listed in Table 1. For general information on these sections, the reader should examine earlier work and work in progress (Table 1).

\section{ZONAL CONCEPTS}

Because the sections to be analyzed came from different latitudes and reflected different water masses and depositional settings, it was not possible in some cases (especially in onland sections) to apply the detailed zonal schemes of Bukry (1973a, 1975), Martini (1971), and Raffi and Rio (1979), which were often based on forms uncommon to Italian sections and on the LADs of species difficult to recognize owing to reworking.

In order to facilitate the comparison, I adopted for the Pliocene interval a less detailed scheme, based mainly on the FADs of widespread species.

For the Pleistocene I followed Gartner (1977b), modifying only the definition of the "small Gephyrocapsae Zone" base, which I identify by the disappearance of "large Gephyrocapsae," since the Helicosphaera sellii LAD is difficult to place in some of the sections (e.g., in Hole 502B, Lamont Piston Core V.26-40).

A brief summary of the zonal concepts I adopted for the Pliocene interval follows.

1) Ceratolithus acutus Zone spans the interval from the reassessment of open marine condition in the Mediterranean (see Raffi and Rio, 1979) to the first appearance of $C$. rugosus.

2) Reticulofenestra pseudoumbilica Zone is defined as the interval between the FAD of $C$. rugosus and the FAD of Pseudoemiliani lacunosa. The latter event is nearly equivalent to the LAD of $R$. pseudoumbilica, which is sometime difficult to recognize (e.g., in DSDP Site 397 and in many Italian onland sections), probably because of reworking. As Discoaster asymmetricus is scarce or absent in Italian sections (e.g., Tabiano), I did not use it as a zonal marker.

3) D. surculus Zone spans the interval between the FAD of $P$. lacunos $a$ and the massive extinction of $D$. surculus/D. pentaradiatus.

4) $D$. brouweri Zone spans the interval between the extinction of $D$. surculus $/ D$. pentaradiatus and the FAD of $G$. oceanica s.l.

In Figure 2, I compare my zonal concepts with others commonly used.

\section{RESULTS}

The detailed nannofossil biostratigraphic data of Holes 502B, 502C, and 503B are reported in Figures 3 and 4 . In Figure 5 (back pocket) shows the distribution of Gephyrocapsae in these sequences as well as in others here considered, with reference to nannofossil biostratigraphy and to other available bio-, chrono-, and magnetostratigraphic information.

Within the framework thus outlined, I discuss in the following paragraphs the Gephyrocapsa distributions. 


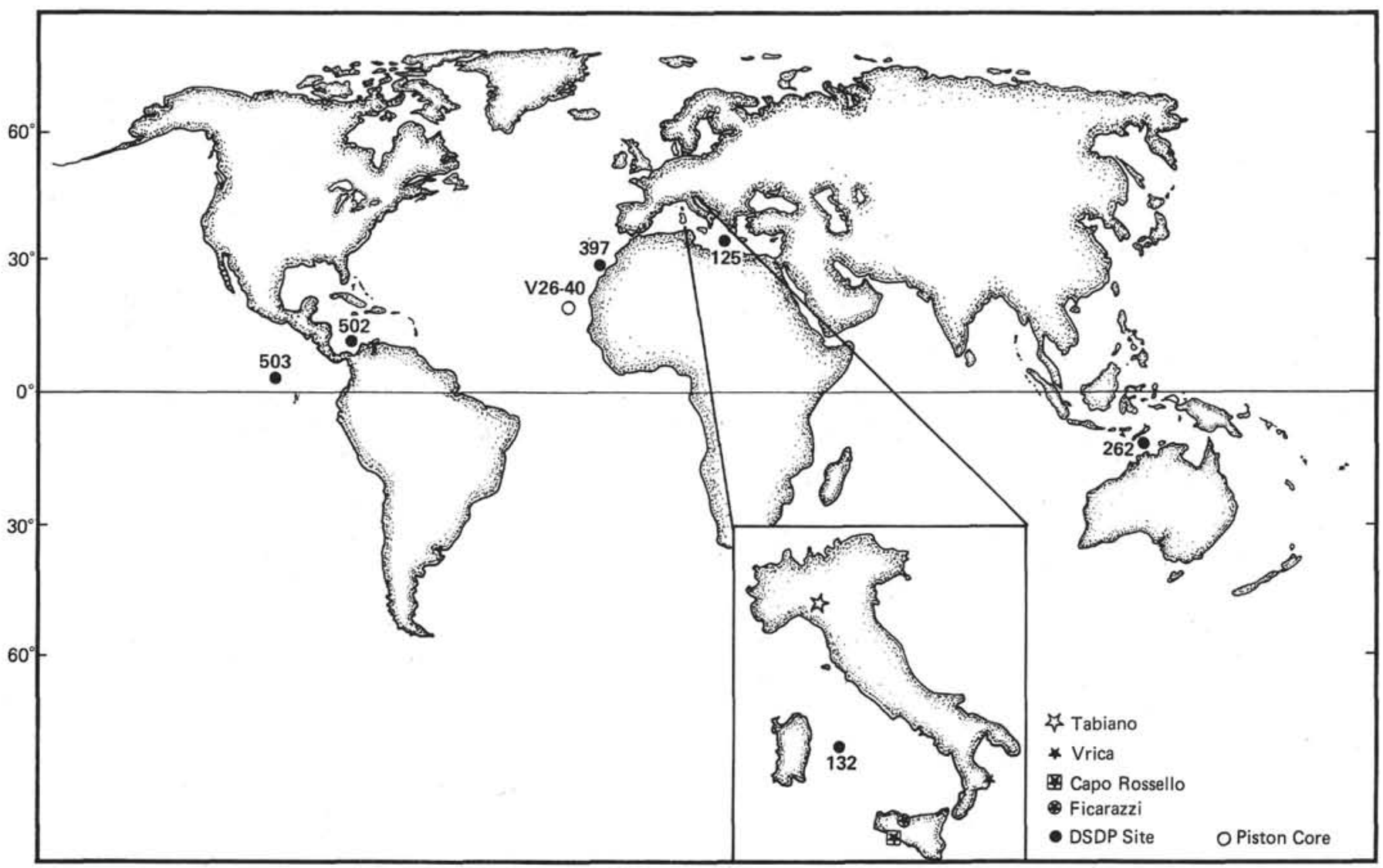

Figure 1. Location map for the investigated sequences.

\section{EARLY DISTRIBUTION OF THE GEPHYROCAPSA COMPLEX}

Until some years ago, it was generally assumed that the first representatives of the Gephyrocapsa genus (often cited as belonging to Gephyrocapsa caribbeanica Boudreaux and Hay) had appeared near the extinction level of $D$. brouweri (for a review, see Sachs and Skinner, 1973; Rio, 1974).

After realizing the importance of the genus for the Plio/Pleistocene boundary biostratigraphy (Rio, 1974; Haq et al., 1977), researchers paid more attention to its early appearance and made several findings at lower stratigraphic levels. Among others, Pirini Radrizzani and Valleri (1977) and Raffi and Rio (1979) found small Gephyrocapsae near the Tabianian/Piacenzian boundary in DSDP Site 132 (Tyrrhenian Sea, western Mediterranean). Gartner (1977a, 1977b) observed them in upper Pliocene (nannofossil Zone NN17) sections of hemipelagic sediments.

In order to investigate the early distributions of $\mathrm{Ge}$ phyrocapsae, I examined DSDP Hole 503B, Site 397, Site 132, and Capo Rossello and Tabiano sections (Fig. 5). Remarkably, in all sections small Gephyrocapsae appear near the FAD of Pseudoemiliania lacunosa. In some sections (Site 132, Hole 503B, Capo Rossello) the Reticulofenestra pseudoumbilica and Sphenolithus spp. LADs are also recorded near their appearance.

In Mediterranean sections, Gephyrocapsae appear near the LAD of Globorotalia margaritae, the marker fossil for the Tabianian/Piacenzian boundary (see Cita, 1973). In this interval, they reach the maximum size of $3.5 \mu \mathrm{m}$ and are easily identified by light microscope (Plate 1, Fig. 1-6). These early Gephyrocapsa findings have also been confirmed by SEM analyses (Plate 4 , Figs. 1-4).

After the short but easily recognizable bloom in the mid-Pliocene, Gephyrocapsae became scarce or absent. They seem to persist more consistently in terrigenous (Tabiano, Capo Rossello) than hemipelagic (Sites 397, 132) and pelagic (Hole 503B) sections. The different distribution patterns may be explained by considering the hemipelagic preference of these forms, as suggested by Gartner (1977b).

\section{THE LATE PLIOCENE-PLEISTOCENE DISTRIBUTION OF THE GEPHYROCAPSA COMPLEX: EVOLUTIONARY TRENDS BY LIGHT MICROSCOPE}

Gephyrocapsae became firmly established in the nannoflora assemblage of the interval between the $D$. surculus LAD and the $D$. brouweri LAD (Fig. 5) and grew to be the dominant coccoliths throughout almost the entire Pleistocene.

During this interval they underwent evident changes, particularly in size. I followed the size variation in detail, in sections from widely separated areas and underlying different water masses (Fig. 6). Remarkable is the gradual increase of maximum size from $2-3 \mu \mathrm{m}$ to $6-7$ $\mu \mathrm{m}$ in all sections during the late Pliocene-early Pleisto- 
Table 1. Locations, general information, and previous studies of the sections investigated in the present study.

\begin{tabular}{|c|c|c|c|c|c|c|}
\hline Section & Location & Lat. & Long. & $\begin{array}{l}\text { Water Depth } \\
\text { (m) }\end{array}$ & Other Information & $\begin{array}{l}\text { Previous Studies on Stratigraphy, } \\
\text { Published or in Progress }\end{array}$ \\
\hline $\begin{array}{l}\text { DSDP Holes } \\
\text { 502B- } \\
\text { 502C }\end{array}$ & $\begin{array}{l}\text { Colombian Basin } \\
\text { Caribbean Sea }\end{array}$ & $11^{\circ} 29^{\prime} \mathrm{N}$ & $79^{\circ} 23^{\prime} \mathrm{W}$ & 3051 & & This volume \\
\hline $\begin{array}{l}\text { DSDP Hole } \\
\text { 503B }\end{array}$ & $\begin{array}{l}\text { Eastern Equatorial } \\
\text { Pacific }\end{array}$ & $4^{\circ} 04^{\prime} \mathrm{N}$ & $95^{\circ} 38^{\prime} \mathrm{W}$ & 3672 & & This volume \\
\hline $\begin{array}{l}\text { DSDP Site } \\
262\end{array}$ & Timor Trough & $10^{\circ} 19^{\prime} \mathrm{S}$ & $123^{\circ} 50^{\prime} \mathrm{E}$ & 2298 & & $\begin{array}{r}\text { Proto Decima (1974, nannofossils) } \\
\text { Rögl (1974, planktonic forams) }\end{array}$ \\
\hline $\begin{array}{l}\text { DSDP Site } \\
397\end{array}$ & $\begin{array}{l}\text { Cap Bojador } \\
\text { Eastern Atlantic }\end{array}$ & $26^{\circ} 50^{\prime} \mathrm{N}$ & $15^{\circ} 10^{\prime} \mathrm{W}$ & 2900 & & $\begin{array}{l}\text { Mazzei et al. (1979, nannofossils) } \\
\text { Hamilton (1979, paleomagnetic } \\
\text { stratigraphy) }\end{array}$ \\
\hline $\begin{array}{l}\text { DSDP Site } \\
132\end{array}$ & $\begin{array}{l}\text { Tyrrhenian Rise } \\
\text { Western Mediterranean }\end{array}$ & $40^{\circ} 15^{\prime} \mathrm{N}$ & $11^{\circ} 26^{\prime} \mathrm{E}$ & 2813 & & $\begin{array}{l}\text { Raffi and Rio (1979, nannofossils); } \\
\text { Colalongo et al. (in preparation, calcareous } \\
\text { nannoplankton); Cita (1973, planktonic } \\
\text { forams) }\end{array}$ \\
\hline $\begin{array}{l}\text { DSDP Site } \\
\qquad 125\end{array}$ & $\begin{array}{l}\text { Ionian Basin } \\
\text { Eastern Mediterranean }\end{array}$ & $34^{\circ} 37^{\prime} \mathrm{N}$ & $20^{\circ} 25^{\prime} \mathrm{E}$ & 2772 & & $\begin{array}{l}\text { Raffi and Sprovieri (in preparation, calcare- } \\
\text { ous nannoplankton) Stradner (1973, } \\
\text { nannofossils); Cita (1973, planktonic } \\
\text { forams); Thunell (1979, planktonic forams) }\end{array}$ \\
\hline $\begin{array}{l}\text { Lamont Core } \\
\text { V26-40 }\end{array}$ & Atlantic & $19^{\circ} 40^{\prime} \mathrm{N}$ & $26^{\circ} 07^{\prime} \mathrm{W}$ & 4530 & & $\begin{array}{l}\text { Raffi and Rio (in preparation, nannofossils); } \\
\text { Morlotti (in preparation, planktonic } \\
\text { forams) }\end{array}$ \\
\hline Tabiano & $\begin{array}{l}\text { Northern Appennines- } \\
\text { Northern Italy }\end{array}$ & $44^{\circ} 46^{\prime} \mathrm{N}$ & $10^{\circ} 01^{\prime} \mathrm{E}$ & & $\begin{array}{l}\text { Tabianian (lower } \\
\text { Pliocene) } \\
\text { Stratotype }\end{array}$ & $\begin{array}{l}\text { Raffi and Rio (in press a, nannofossils); } \\
\text { Iaccarino (1967, planktonic forams); } \\
\text { Colalongo et al. (1974, planktonic forams) }\end{array}$ \\
\hline $\begin{array}{l}\text { Capo } \\
\quad \text { Rossello }\end{array}$ & Agrigento (Sicily) & $37^{\circ} 17^{\prime} \mathrm{N}$ & $13^{\circ} 28^{\prime} \mathrm{E}$ & & $\begin{array}{l}\text { Zanclean (lower } \\
\text { Pliocene) Neo- } \\
\text { stratotype }\end{array}$ & $\begin{array}{l}\text { Raffi et al. (in preparation, calcareous } \\
\text { nannoplankton) Sprovieri (1978, benthonic } \\
\text { forams) Cita and Gartner (1973, calcareous } \\
\text { nannoplankton) }\end{array}$ \\
\hline Vrica & $\begin{array}{l}\text { Calabria- } \\
\text { Southern Italy }\end{array}$ & $39^{\circ} 03^{\prime} \mathrm{N}$ & $17^{\circ} 07^{\prime} \mathrm{E}$ & & $\begin{array}{l}\text { Plio/Pleistocene } \\
\text { Boundary } \\
\text { Stratotype }\end{array}$ & $\begin{array}{l}\text { Selli et al. (1977, general stratigraphy); } \\
\text { Colalongo et al. (multiple biostrat.), 1980; } \\
\text { Raffi and Rio (unpublished, nannofossils) }\end{array}$ \\
\hline Ficarazzi & Palermo (Sicily) & $38^{\circ} 07^{\prime} \mathrm{N}$ & $13^{\circ} 22^{\prime} \mathrm{E}$ & & Sicilian Stratotype & $\begin{array}{l}\text { Di Stefano and Rio (in press, nannofossils); } \\
\text { Sprovieri (in preparation, planktonic } \\
\text { forams) }\end{array}$ \\
\hline
\end{tabular}

cene interval $(D$. brouweri Zone-base of the small $G e$ phyrocapsae Zone).

Within the small Gephyrocapsae Zone, normal-sized and large species disappear.

The differences above and below this zone interval are conspicuous.

1) Morphotypes larger than $5.5 \mu \mathrm{m}$ occur only below the interval. In these forms the diagonal bar always occurs at an angle of $45^{\circ}$ or more to the short axis. Within this group are morphotypes with either a wide open (Plate 2, Figs. 4, 5, 7, 9, and 10) or a closed central area (Plate 2, Figs. 11, 12).

2) Morphotypes 4-5.5 $\mu \mathrm{m}$ (Plate 3, Figs. 1-10), with the diagonal bar aligned or nearly aligned with the short axis, appear only above this interval (Fig. 5).

3) Other features, such as rim structure and outline, too subtle to detect by light microscope, seem to change, but a more detailed analysis is needed to demonstrate these changes definitively.

According to the foregoing observations, the gradual size increase in the lower Pleistocene may be regarded as a true evolutionary trend not related to local ecology, since it is consistent in all sections. Also, the orientation of the bridge relative to the short axis in forms larger than $4 \mu \mathrm{m}$ seems to be a feature that developed late (above the small Gephyrocapsae Zone) in the evolution of the genus. On the other hand, there is no definitive trend concerning the opening of the central area, which might depend mainly on ecological conditions, as suggested by Gartner $(1973,1977 b)$ and Bukry (1973b).

\section{SUBDIVISION OF THE GEPHYROCAPSA COMPLEX BY LIGHT MICROSCOPE}

On the basis of the results, we may conclude that correlations can be made (Figs. 5 and 8 ) even with an informal approach based on size and that, therefore, the main goal of nannofossil paleontology can be achieved.

Although a series of almost indistinguishable transitional forms occur, preventing the definition of precise species limits, some end morphotypes, delimited by light microscope on the basis of easily detectable features, seem to be stratigraphically restricted.

Because of the wide morphologic variations in living cells, ${ }^{2}$ restricted stratigraphic distribution seems to be a sounder basis for taxonomic delimitations within calcareous nannofossils.

The present results suggest therefore the opportunity of creating new subspecies of $G$. oceanica for the following stratigraphically restricted morphotypes (Raffi and Rio, in preparation).

1) Gephyrocapsa oceanica $\mathrm{sp}_{1}$, including morphotypes larger than $6 \mu \mathrm{m}$, with a closed central area. These

\footnotetext{
${ }^{2}$ Some morphologic variations are due to polymorphism (Markali and Paasche, 1955; Gaarder, 1970; Clocchiatti, 1971; Borsetti and Cati, 1972), some to phase changes in life cycles (Parke and Adams, 1960; Parke, 1971), and some to environmental stress (Mclntyre et al., 1967; Watabe and Wilbur, 1966; Okada and Honjo, 1973).
} 


\begin{tabular}{|c|c|c|c|c|c|}
\hline \multicolumn{2}{|c|}{$\begin{array}{l}\text { Tropical } \\
\text { Bukry, } 1975\end{array}$} & \multirow{4}{*}{$\begin{array}{c}\begin{array}{c}\text { Standard } \\
\text { Martini, 1971 }\end{array} \\
\text { Zone } \\
\text { E. huxleyi NN21 }\end{array}$} & \multicolumn{2}{|c|}{$\begin{array}{c}\text { Mediterranean } \\
\text { Raffi and Rio, } 1979\end{array}$} & \multirow{2}{*}{$\begin{array}{c}\text { Adopted } \\
\text { Zone }\end{array}$} \\
\hline Zone & Subzone & & Zone & Subzone & \\
\hline \multirow{2}{*}{\multicolumn{2}{|c|}{ E. huxleyi }} & & \multicolumn{2}{|l|}{ E. huxleyi } & E. huxleyi acme \\
\hline & & & \multicolumn{2}{|l|}{ E. huxleyi } & E. huxleyi \\
\hline \multirow{2}{*}{ G. oceanica } & Cer. cristatus & G. oceanica NN20 & \multicolumn{2}{|l|}{ G. oceanica } & G. oceanica \\
\hline & $\left\{\begin{array}{l}\text { E. ovata } \\
-?---?-- \\
\text { G. caribbeanica }\end{array}\right.$ & \multirow{4}{*}{ P. lacunosa NN21 } & \multirow{4}{*}{ P. lacunosa } & Syr. pulchra & P. lacunosa \\
\hline \multirow{4}{*}{ Cren. doronicoides } & \multirow{3}{*}{ G. caribbeanica } & & & small Gephyrocapsae & small Gephyrocapsae \\
\hline & & & & Helic. sellii & Helic. sellii \\
\hline & & & & Cycl. macintyrei & Cycl. macintyrei \\
\hline & E. annula & \multirow{2}{*}{ D. brouweri NN18 } & \multirow{2}{*}{ C. pelagicus } & Cren. doronicoides & \multirow{2}{*}{ D. brouweri } \\
\hline \multirow{4}{*}{ D. brouweri } & Cycl. macintyrei & & & D. brouweri & \\
\hline & D. pentaradiatus & D. pentaradiatus NN17 & \multirow{3}{*}{ D. surculus } & P pentaradiatus & \multirow{3}{*}{ D. surculus } \\
\hline & D. surculus & \multirow{2}{*}{ D. surculus NN16 } & & & \\
\hline & D. tamalis & & & D. tamalis & \\
\hline \multirow{2}{*}{ R. pseudoumbilica } & D. asymmetricus & \multirow{2}{*}{$\begin{array}{l}\text { R. pseudoumbilica } \\
\text { NN15 }\end{array}$} & \multirow{3}{*}{\multicolumn{2}{|c|}{ R. pseudoumbilica }} & \multirow{4}{*}{ R. pseudoumbilica } \\
\hline & Sph. neoabies & & & & \\
\hline \multirow{3}{*}{ Cer. tricorniculatus } & \multirow{2}{*}{ Cer. rugosus } & D. asymmetricus & & & \\
\hline & & Cer. rugosus & \multirow{2}{*}{ A. delicatus } & Cer. rugosus & \\
\hline & Cer. acutus & Cer. tricorniculatus & & Amaurolithus spp. & Cer. acutus \\
\hline
\end{tabular}

Figure 2. Correlation of the nannofossil zonation in the present study with previously established biozonations. (See the text for zonal boundaries.)

forms are restricted to the lower Pleistocene and are reminiscent of Gephyrocapsa lumina Bukry, 1973b (Plate 2, Figs. 11-12).

2) Gephyrocapsa oceanica $\mathrm{sp}_{2}$, including morphotypes larger than $5.5 \mu \mathrm{m}$, with an open central area. These forms are restricted to the lower Pleistocene (Plate 2, Figs. 4, 5, 7, 9, 10).

3) Gephyrocapsa oceanica $\mathrm{sp}_{3}$, including morphotypes 4-6 $\mu \mathrm{m}$, with the diagonal bar aligned with the short axis. These forms appear in the assemblage only after the small Gephyrocapsae interval, at the beginning of the middle Pleistocene (Plate 3, Figs. 1-10).

It is noteworthy that all these subspecies can be recognized by light microscope and are therefore useful to stratigraphy by providing supplementary data for biostratigraphic classification where other commonly used nannofossil events cannot be easily determined-for example in Italian onland sections.

\section{BIOCHRONOLOGY OF THE GEPHYROCAPSA COMPLEX}

In this section I discuss the time calibration (biochronology) of the Gephyrocapsa morphotypes. Since time-calibrated isochronous widespread biostratigraphic events are the primary tool for long-distance correlations in Phanerozoic sediments (Haq and Berggren, 1978), it is important for our purposes to recognize Mediterranean epoch and age boundaries worldwide.
Biochronologic evaluation can be satisfactorily carried out by relating biostratigraphic events to a nonbiological time framework such as magnetic stratigraphy; for the sequences we are studying, however, it is available only for Site 397 (Hamilton, 1979) and Holes 502B and 503B (Kent and Spariosu, this volume). Therefore, in order to obtain further clues to time evaluation, I related Gephyrocapsa morphotypes to other biochronologic datum events and to the few available radiometrically dated levels.

Looking carefully at the data in Figure 5, one notes first that Gephyrocapsa morphotype distribution is fairly regular with respect to other datum events provided by nannofossils and planktonic foraminifers. This should indicate that if there is diachroneity, the time difference involved is small compared to our present powers of stratigraphic resolution.

The first appearance of Gephyrocapsa genus can be directly calibrated by magnetostratigraphy in Hole 503B at $\sim 3.64 \mathrm{Ma}$ (Fig. 7). In the same sequence, P. lacunosa FAD is calibrated at $3.51 \mathrm{Ma}$.

A rather different age (Cochiti, ca. 3.9 Ma) for these two events is established in DSDP Site 397 (Fig. 5), but we must be cautious about this calibration, since the paleomagnetic record of drilled sequences is affected by many factors.

In Mediterranean sections the FAD of $P$. lacunosa with the accompanying small Gephyrocapsa FAD occurs remarkably near the G. margaritae LAD (Fig. 5), which 


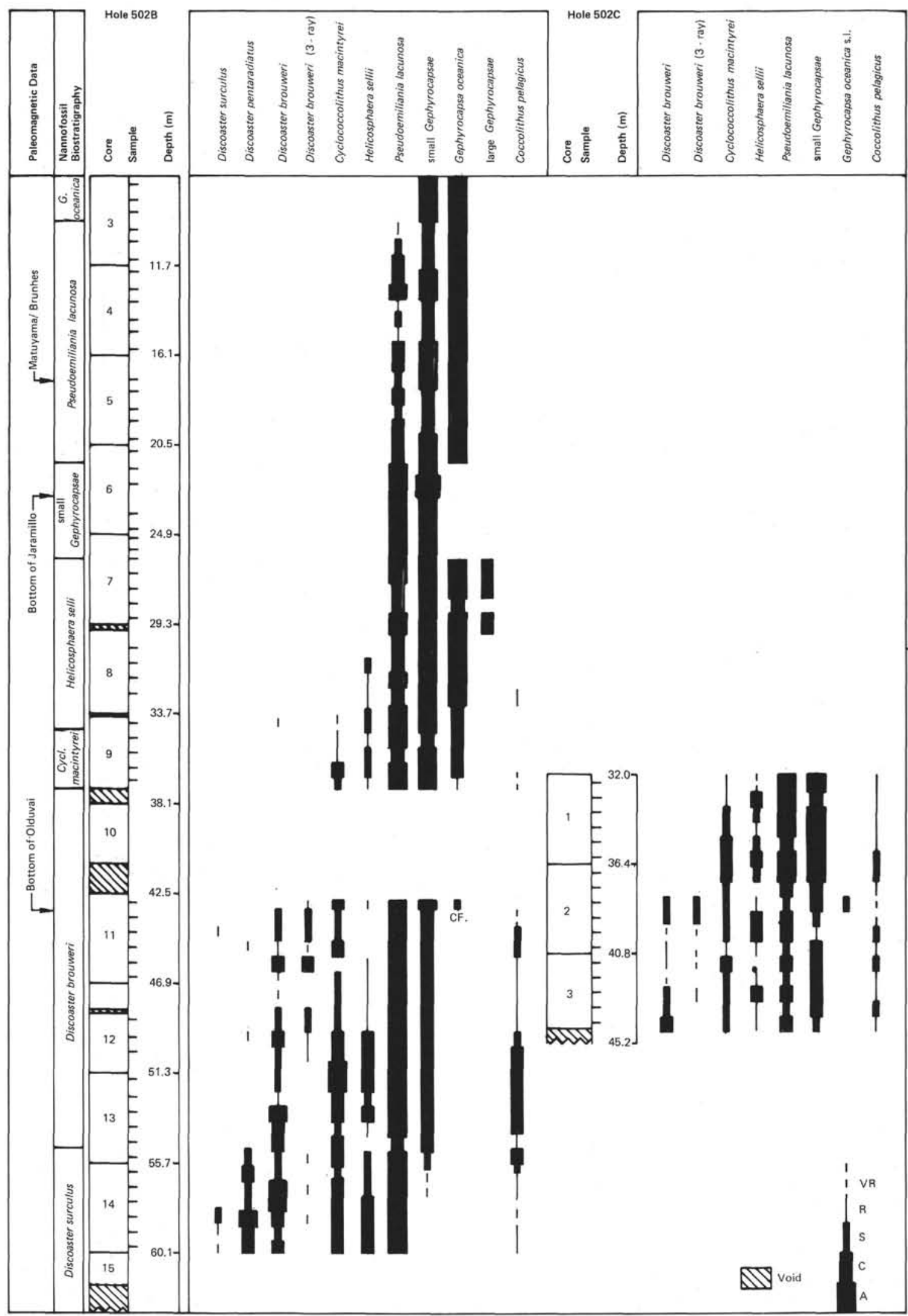

Figure 3. Ranges of selected nannofossil species in DSDP Holes 502B and 502C. Species abundances (all fields of view at $\times 1200$ : $(A=$ more that 1 specimen of a species in each field of view; $C=1$ specimen of a species in $1-10$ fields of view; $\mathrm{S}=1$ specimen of a species in every 10 fields of view; $\mathrm{R}=$ very few specimens encountered in 100 fields of view; $\mathrm{VR}=$ very few specimens only after supplementary analyses. 


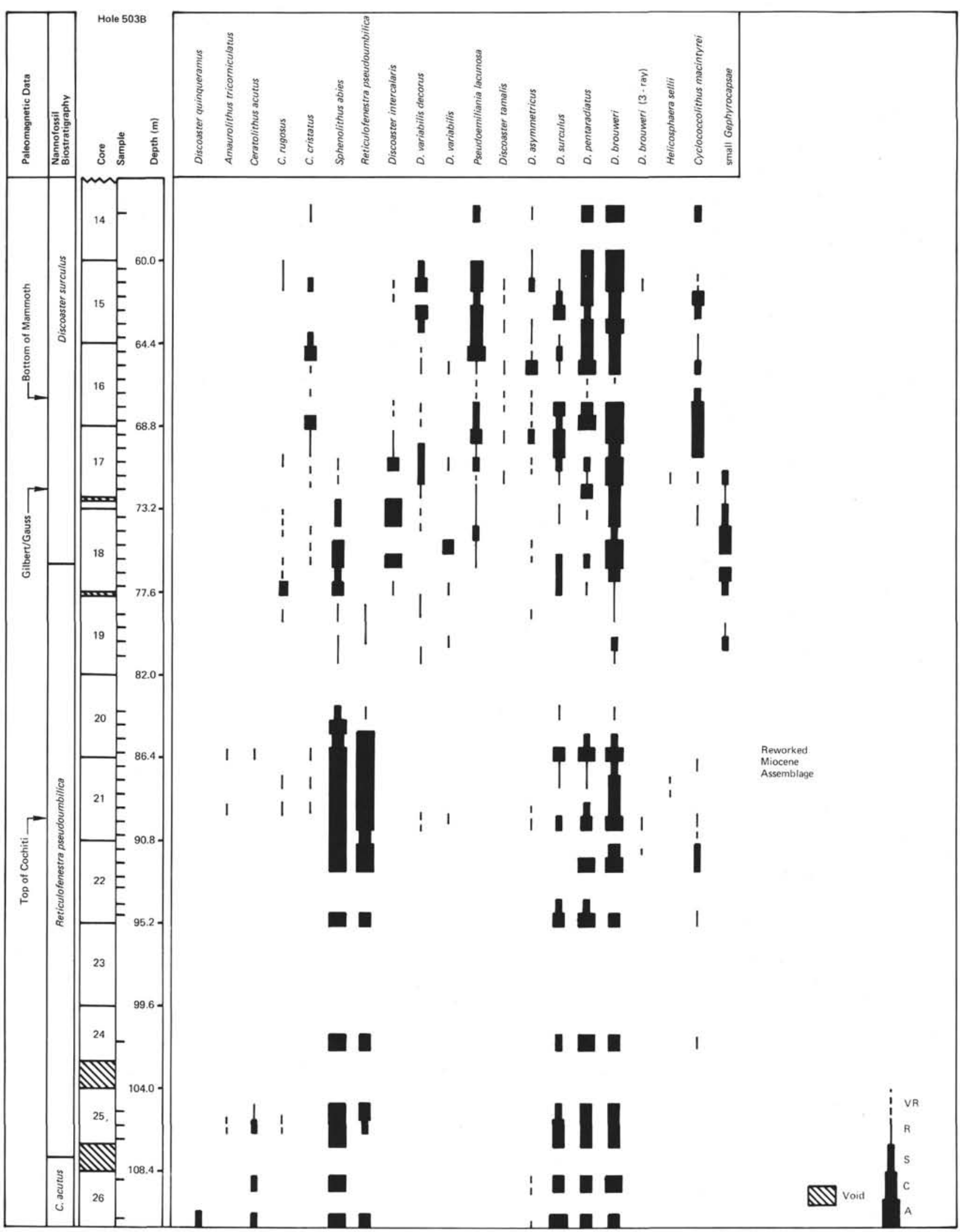

Figure 4. Ranges of selected nannofossil species in DSDP Hole 503B. Species abundances as in Figure 3. 
had previously been calibrated at the Gilbert/Gauss boundary at $3.4 \mathrm{Ma}$ (Cita, 1973).

All these evidences suggest an age no younger than the base of the Gauss and no older than the Cochiti for the first appearance of Gephyrocapsa. This should represent the age of the Tabianian (lower Pliocene)/Piacenzian (upper Pliocene) boundary.

Volcanic ash levels in the lower Piacenzian in the Lazio region (Arias et al., 1967) and in Calabria (Selli, in Cita, 1973) have provided ages of $4.03 \pm 0.93$ and 3.4 $\mathrm{Ma}$, respectively, which are basically in agreement with the biochronologic evaluation reported here for the lower/upper Pliocene boundary.

Small Gephyrocapsae became common in the assemblage in Hole 502B in the lower Matuyama near the $D$. pentaradiatus $\mathrm{LAD}$, but according to the other distributions (Fig. 5) and to Gartner's data (1977b), they seem to proliferate at different times in different environmental settings. In fact, in pelagic sediments (Gartner, 1977b) they appear as high as the extinction level of D. brouweri, calibrated near the top of the Olduvai.

The first appearance of $G$. oceanica s.l. can be directly calibrated by magnetic stratigraphy in Holes 502B and C (Figs. 3 and 4). In Hole 502B, G. oceanica s.l. was first recorded at ca. 43 meters (Plate 1, Figs. 9, 11, 12), where $D$. brouweri and 3-rayed $D$. brouweri still occur and where the base of the Olduvai has been recognized by Kent and Spariosu (this volume). Unfortunately, above this level there is an unrecovered, ca. 5.5-meterthick interval where, obviously, no observations can be made. In the first sample after this gap, G. oceanica s.l. is again present and continuously distributed.

For a better evaluation of the early distribution of this form, I investigated Cores 1, 2, and 3 of adjacent Hole $502 \mathrm{C}$ so as completely to overlap the unsampled interval of Hole 502B. I noted that in this sequence $G$. oceanica s.l. occurs together with $D$. brouweri and 3-rayed D. brouweri at ca. 38 meters (Fig. 3). I considered this level to correspond to that in Hole 502B, just below the unsampled interval. Above, no specimens of $G$. oceanica s.l. were recorded.

Because of these data, I regard as FAD of $G$. oceanica s.l. its first common and continuous occurrence at ca. 37 meters in Hole 502B, just above the Olduvai Subchron (Fig. 7), although its very first presence is recorded as early as the base of the Olduvai Subchron. Accordingly Gartner (1977b) and Haq et al. (1977) evaluated the FAD of $G$. oceanica Kamptner at the same position in time.

A similar age, just above the top of the Olduvai Subchron, is suggested by the distribution of $D$. brouweri and Globorotalia truncatulinoides in some of the investigated sections (Fig. 5). In fact, Gephyrocapsa oceanica s.l. FAD is little above (Sites 125,132 ) the $D$. brouweri LAD, calibrated within the Olduvai Subchron (Haq et al., 1977) and well above (Site 125, Capo Rossello section) the FAD of Globorotalia truncatulinoides truncatulinoides, calibrated just below the base of the Olduvai Subchron (Haq et al., 1977).

A slightly older age than the top of the Olduvai Subchron is suggested by the radiometric age of an ash level ca. 10 meters above the Gephyrocapsa oceanica s.l.
FAD in the Vrica section, dated at $2.01 \pm 0.33$ by Selli et al. (1977).

In conclusion, we may assume for the G. oceanica s.l. FAD an age of ca. 1.60-1.70 Ma. As for other events in the Gephyrocapsa complex, it is possible to calibrate (Fig. 7) the large Gephyrocapsa FAD in Hole 502B at ca. 1.3 Ma and both the beginning and the end of the small Gephyrocapsa interval at ca. 1.13 and $0.91 \mathrm{Ma}$, respectively.

\section{CORRELATION OF UPPER PLIOCENE-LOWER PLEISTOCENE OCEANIC AND MEDITERRANEAN RECORDS VIA THE GEPHYROCAPSA COMPLEX}

Since Gephyrocapsae are abundant in Italian and reference sections and underwent the same evolutionary trends in Mediterranean and oceanic areas (Fig. 6), they seem to be a useful and reliable tool for correlating Italian chronostratigraphic units with other geologic records. In the light of the Gephyrocapsa distributions and biochronology, I discuss in the following sections the chronostratigraphic problem of the Plio/Pleistocene boundary and the lower Pleistocene classification.

\section{THE PLIO/PLEISTOCENE BOUNDARY}

The Plio/Pleistocene boundary is one of the most controversial chronohorizons in the International Geochronologic Scale, mainly as a consequence of different philosophical approaches to stratigraphy (Pelosio et al., 1980). Even within the approach recommended by the International Stratigraphic Guide (which demands that all time stratigraphic units be defined by lithostratigraphic features), controversy arises because of the lack of a precise and globally accepted section where the boundary may be defined. In fact, in recent years, three sections have been considered for defining the Plio/ Pleistocene boundary, with more or less success: S. Maria di Catanzaro (Selli, 1971), Le Castella (Emiliani et al., 1961), and Vrica (Selli et al., 1977).

Since there is general agreement among authors (Haq et al., 1977; Pelosio et al., 1980; Colalongo et al., 1980) that the section of S. Maria di Catanzaro is unsuitable for defining the base of Pleistocene, I will not discuss it further. On the other hand, the two other sections require evaluation, since they represent contrasting definitions of the Plio/Pleistocene boundary.

\section{Le Castella}

The Le Castella section (Crotone Basin, Calabria, southern Italy) was proposed as the Plio/Pleistocene boundary stratotype at the INQUA Congress in Denver (1965), the boundary located according to the level ("marker bed") where the first appearance of the benthic foraminifer Hyalinea baltica is recorded.

This section has a fairly high abundance of planktonic fossils, suitable for long-distance correlations. Unfortunately, the part which can be confidently reconstructed is vertically short (Venzo, 1975), and its biostratigraphic interpretation has therefore been a subject of controversy (Pelosio et al., 1980).

Recent biostratigraphic analyses (Colalongo et al., 1980; Raffi and Rio, in press c) based on foraminifers, ostracodes and nannofossils suggest a hiatus just below 


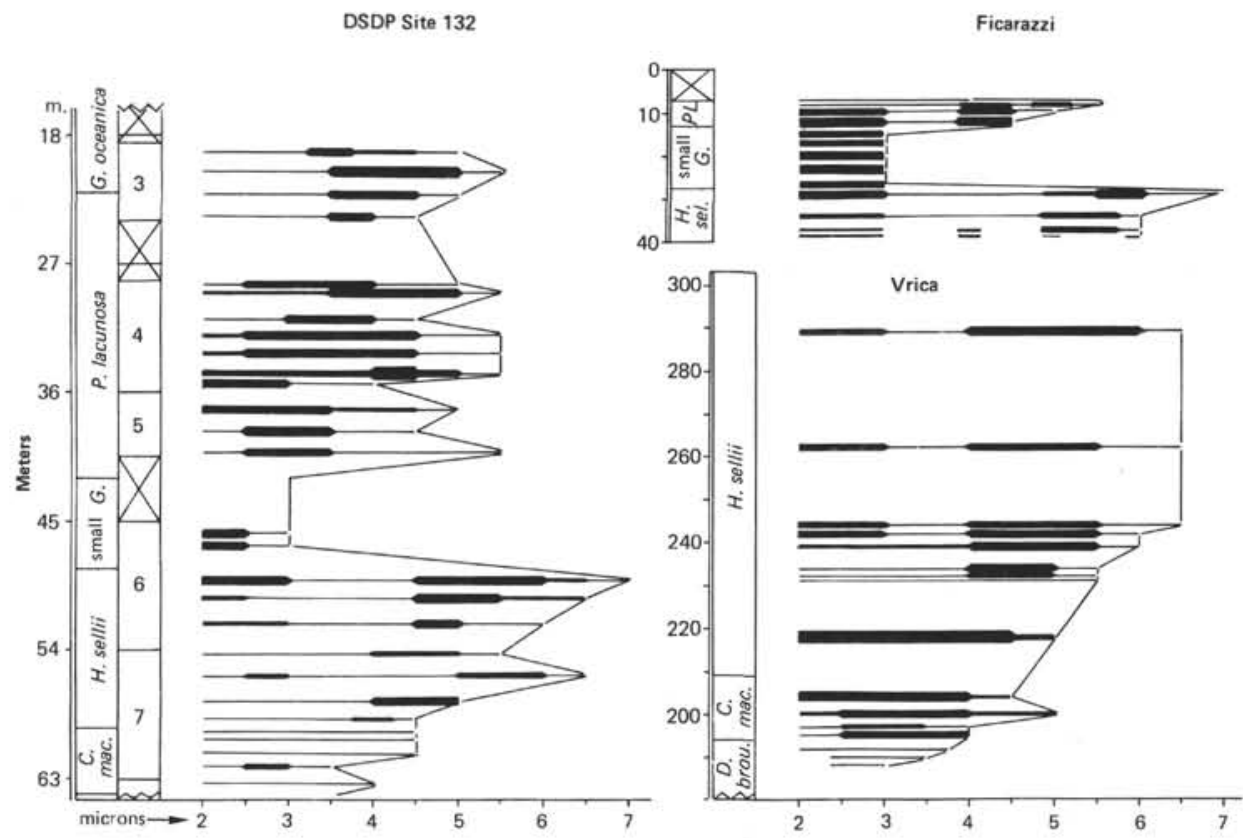

Figure 6. Maximum size variation of Gephyrocapsae in the uppermost Pliocene and Pleistocene. Analyses were carried out by light microscope on at least 300 Gephyrocapsae in each sample, evaluating their abundances, which are graphically represented by the different thicknesses of the horizontal lines.

the marker bed. On this point, the Gephyrocapsa complex distribution is highly significant; in fact, the simultaneous appearance of both $G$. oceanica s.l. and large Gephyrocapsae is recorded just below the marker bed (Fig. 8), whereas they appear at different times in all sequences in the present study (Figs. 6 and 8 ) as well as in many other Italian sections (Raffi and Rio, in press b). This gap in sedimentation, around the Plio/Pleistocene boundary definition level, makes the section unsuitable as a good stratotype (Hedberg, 1976).

Furthermore, the chronologic position of the marker bed is more recent (by a detectable time lag [see Fig. 8]) than the beginning of the Pleistocene, as most Italian authors agree (Pelosio et al., 1980) and as recognized in the Piacenzian (upper Pliocene) stratotype (sensu Colalongo et al., 1974) at Castell'Arquato. To accept the marker bed as the definition of the Plio/Pleistocene boundary would mean to allow for an interval of geologic time not represented in the International Geochronologic Scale (Fig. 8).

\section{Vrica}

The Vrica section (Crotone Basin, Calabria, southern Italy) has been recently proposed as a stratotype for the Plio/Pleistocene boundary. Since the moment the proposal was made, the section has met with unanimous approval from stratigraphers (see Nikiforova and Alekseev, 1978; Pelosio et al., 1980). Indeed, the Vrica section seems to provide all the features required for a satisfactory definition of the boundary: good vertical development, abundant marine planktonic fossils, presence of an isotopically datable level, and so forth.

No official decision has yet been taken as far as the lithostratigraphic level that should define the boundary. Nevertheless, in order to respect a practice more than a century old and avoid gaps between the base of Pleistocene and the top of Pliocene, it seems obligatory to define the boundary in the lithologic level recording the appearance of the first northern immigrants in the Mediterranean (Colalongo et al., 1980; Pelosio et al., 1980). In the deep-water section of Vrica, the first northern "guest" is the ostracode Cytheropteron testudo, whose appearance seems to be reasonably time-equivalent (Raffi and Rio, in press b) to that of Arctica islandica, the pelecypod traditionally used in shallow-water sequences in Italy to identify the Pleistocene. The lithological level where C. testudo is first recorded is at 17 meters in Selli's columnar section and therefore should mark the Plio/Pleistocene boundary.

\section{Age of the Plio/Pleistocene Boundary}

A basic condition for establishing a time boundary in a stratotype section is that it be at least roughly identified in other geologic records. To this purpose, it must be chronologically evaluated-that is, located in geologic time.

There are many different methods for achieving this goal in the Vrica section. Among them, the most directly available are radiometric dating, magnetostratigraphy, and calcareous nannoplankton biochronology.

An ash layer, 25 meters above the boundary definition level, has been dated by Selli et al. (1977), who assigned it an age of $2.07 \pm 0.33 \mathrm{Ma}$. The magnetostratigraphy of the section has not yet been firmly established (G. Pasini, personal communication), so that no definitive conclusions can be drawn. As for biochronology, which is the principal concern here, it is possible to apply to the Vrica section the biochronologic framework established in this report for Gephyrocapsae, which are well represented in the section and underwent the 
Core V26-40

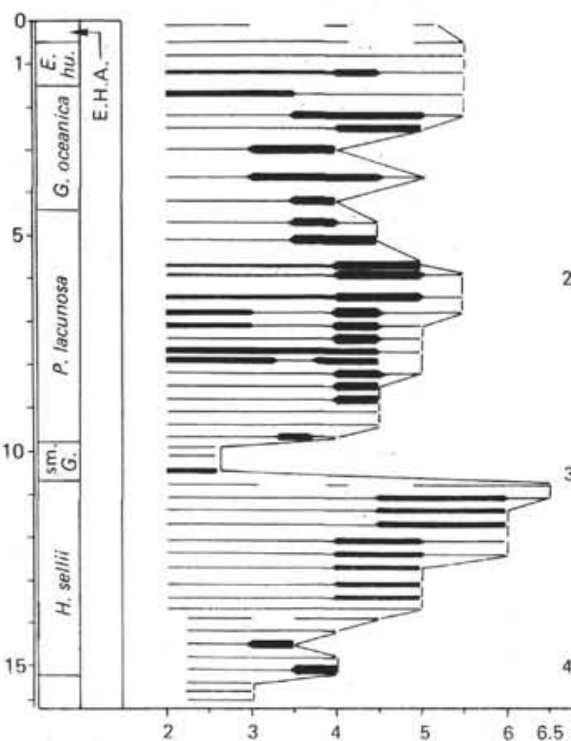

DSDP Hole 502B

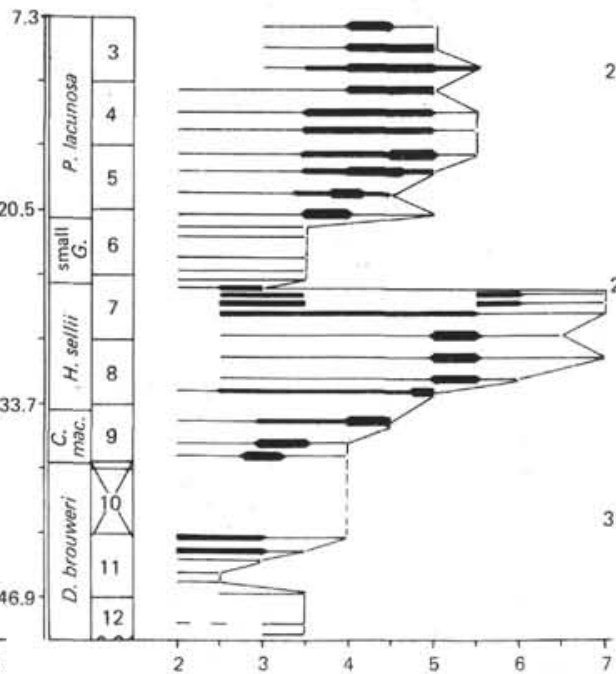

DSDP Site 262

Figure 6. (Continued).

same morphologic evolution noted in the other Mediterranean and extra-Mediterranean sequences (Fig. 6). Since $G$. oceanica s.l. FAD is recorded just above the Plio/ Pleistocene boundary definition level (Figs. 5, 8), an age of about 1.60-1.70 Ma may be derived for the beginning of the Pleistocene. This evaluation is basically in agreement with the radiometric age of the ash layer and with the recent finding of Globorotalia truncatulinoides truncatulinoides in Mediterranean upper Pliocene sediments (Sprovieri et al., in press; Rio et al., in preparation), whose FAD in the oceanic record has been calibrated just below the Olduvai Subchron (Haq et al., 1977).

These data indicate that the Plio/Pleistocene boundary is very close to or slightly younger than the top of the Olduvai. However, we do not presume that it represents the correct age of this chronohorizon, because of the many factors which affect fossil distributions. In order definitively to assess the age of the Plio/Pleistocene boundary, we need a reliable paleomagnetic stratigraphy and such additional time evaluations as climatostratigraphy. In fact, only by combining the contributions of every method of age determination, can the precise position in time of this chronohorizon be affirmed. Conversely, the possibility of applying and crosschecking each available method is the main advantage of defining chronostratigraphic units or horizons by means of stratotypes (Hedberg, 1978).

\section{LOWER PLEISTOCENE CHRONOSTRATIGRAPHY: CALABRIAN, SANTERNIAN, EMILIAN, SICILIAN}

The chronostratigraphic classification of the Quaternary System is known to be in such confusion that many authors propose to abandon it (e.g., Kukla, 1975; Cooke, 1973). Actually, the Pleistocene marine stages, which are defined in Italy, are beset by so many difficulties of definition and correlation that they have been used at most only in Italy.

Until some years ago, the stage names generally used for the lower Pleistocene were Calabrian, Emilian, and Sicilian (Van Eysinga, 1975; Berggren and Van Couvering, 1974). In order to identify the beginning of the successively younger Calabrian, Emilian, and Sicilian, Ruggieri and coworkers (1976) proposed the use of invertebrate fauna events such as the FADs of Arctica islandica, Hyalinea baltica, and Globorotalia truncatulinoides excelsa ( $G$. truncatulinoides of Italian authors [Sprovieri et al., in press]).

Soon afterward, the same authors (Ruggieri and Sprovieri, 1977) proposed a new stage, Santernian, to replace Calabrian, considered to be a junior synonym of Sicilian. These proposals were criticized by Haq et al. (1977) on the grounds that because the aforementioned paleontologic events concern benthic forms which are exceptionally sensitive to environmental control ( $A$. islandica, $H$. baltica) and a taxon ( $G$. truncatulinoides excelsa) uncommon in the Italian Pleistocene, there is no guarantee of their time significance. ${ }^{3}$

Calcareous nannofossils occur in the sections where these facies fossils are distributed, so that it is possible to approach the issue by means of the Gephyrocapsa complex.

Recent analyses (Raffi and Rio, in press b) (Fig. 7) show the following:

1) A. islandica first entered the Mediterranean together with other northern immigrants near the level of the $G$. oceanica s.l. FAD.

\footnotetext{
${ }^{3} \mathrm{Haq}$ et al, (1977) base most of their argument on the fact that they found $H$. baltica in Pliocene sediments 30 meters below the marker bed at Le Castella. Actually, among the many authors who studied this section no one else has ever recorded this form below the marker bed. Doubts about the sampling by Haq et al. are, therefore, more than appropriate.
} 


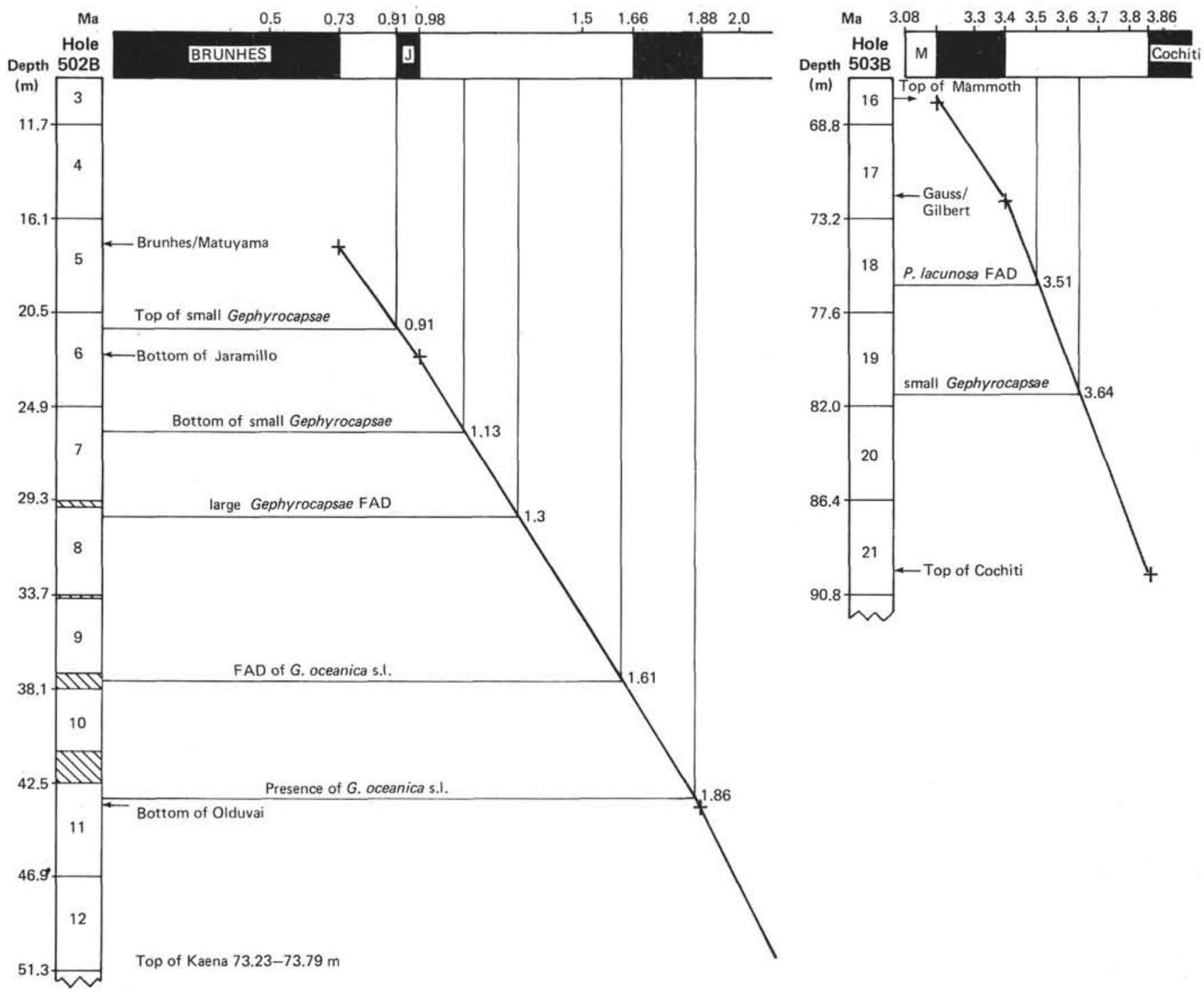

Figure 7. Calibration of Gephyrocapsa complex morphotypes in Holes 502B and 503B. Ages are obtained by extrapolating the sedimentation rates between the paleomagnetic boundaries determined by Kent and Spariosu (this volume) and indicated by arrows in the columnar sections.

2) $H$. baltica arrived only after a certain time lag, as demonstrated by the following data: (1) in all sections where the facies is suitable to both fossils, the appearance of $A$. islandica and $H$. baltica are well separated; (2) in all Italian sections (Raffi and Rio, in press b and Figs. 5 and 7) $H$. baltica appears when "large forms" are present or have just appeared in the Gephyrocapsa assemblage. This can also be observed in the Emilian stratotype in the Santerno section (Raffi and Rio, in press b).

3) Globorotalia truncatulinoides excelsa appeared in the Mediterranean (Rio et al., in preparation), either just below (Le Castella, Site 125) or just above (Ficarazzi, Site 132) the base of the small Gephyrocapsae Zone (see also Fig. 8).

According to these data, the threefold biostratigraphic subdivision of the lower Pleistocene proposed by Ruggieri and coworkers (1976) maintains a chronologic significance.
Looking at the calibration of the nannofossil events, the base of the Emilian would be at ca. 1.3 and the base of Sicilian at ca. 1.2 Ma. The top of this stage has not yet been defined, but since the highest outcropping terrains in Ficarazzi type locality are within the lower part of Gartner's P. lacunosa Zone (Di Stefano and Rio, in press), it may be assigned an age slightly younger than that of the Jaramillo Subchron.

The three Mediterranean stages may be recognized at least approximately by means of nannofossils in other geologic records. Nevertheless, the opportunity of maintaining such "short" stages in the International Geochronologic Scale is rather questionable. In fact, they span a time interval between the Olduvai and the Jaramillo Subchron, where no other method of correlation of worldwide value (except nannofossil events) are well established. It seems more convenient to consider the Santernian, Emilian, and Sicilian as chronostratigraphic units of lower rank rather than stages and to maintain a 


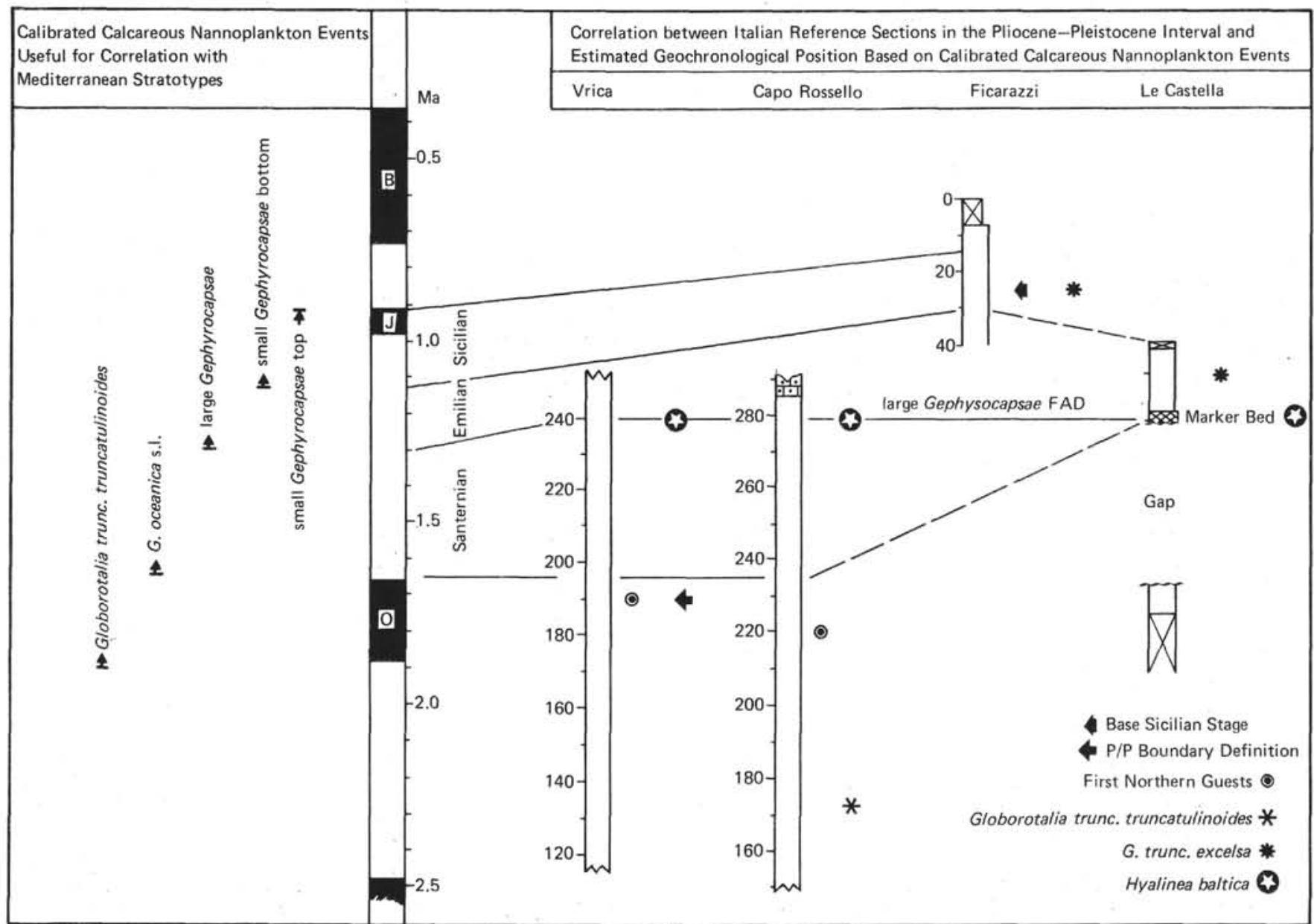

Figure 8. Plio-Pleistocene calcareous nannoplankton biochronology, estimated approximate age of the Plio/Pleistocene boundary, and estimated position in time of Mediterranean lower Pleistocene stage-ages.

unique stage for the lower Pleistocene, as do most authors (see Bowen, 1978).

\section{CONCLUSIONS}

The light microscopy study of the distribution of the Gephyrocapsa complex in sections from widely separated areas confirms the usefulness of these nannofossils for the biostratigraphic classification of the Plio-Pleistocene interval. Even with an informal, non-Linnaean taxonomic approach based on size, it is possible to follow substantial successive morphologic changes, which in turn allow correlations in widely separated regions.

I have found that, with reference to Italian sections, small representatives of the genus appear as early as the top of the lower Pliocene, near the top of the NN15 Zone of Martini's Standard Zonation. After a short bloom near the Tabianian/Piacenzian boundary, recorded in all sections in different water masses, Gephyrocapsae become scarce or absent, being more abundant in terrigenous and hemipelagic sections. At slightly different times, they become common in the nannoflora assemblage in the uppermost Pliocene (top of NN17 and base of NN18) and grow to be the dominant forms in the Pleistocene. During the upper Pliocene-lower Pleistocene, they undergo marked morphologic changes, which can be observed by light microscope. A trend toward larger size in the lower Pleistocene is clearly evident, which can be stratigraphically useful. In particular, forms larger that $6 \mu \mathrm{m}$ seem to be restricted to the lower Pleistocene.

Another important morphological change concerns the alignment of the diagonal bar and the short axis in the placolith. In normal-sized forms, this feature is reached only in the mid-Pleistocene, after Gartner's small Gephyrocapsae Zone.

The paleomagnetic stratigraphy of Holes 502B and 503B allows us to calibrate the appearance of these different morphologic groups. Small Gephyrocapsae and Pseudoemiliania lacunosa appear in the upper part of the Gilbert (near 3.5-3.6 Ma), which is the most probable age of the Tabianian/Piacenzian boundary.

Normal-sized Gephyrocapsae (labeled here G. oceanica s.1.) appear at the top of the Olduvai Subchron. In the Italian sections, including the Vrica stratotype, this subchron is recorded just above the base of the Pleistocene. An approximate age of 1.6-1.7 Ma is therefore estimated for the Plio/Pleistocene boundary, which is in agreement with the recent finding of Globorotalia truncatulinoides truncatulinoides in the Mediterranean Pliocene (Sprovieri et al., in press; Rio et al., in preparation). 
On the basis of the Gephyrocapsa evolution, I was able to position in time the Mediterranean lower Pleistocene marine stages: Santernian, $1.6-1.7$ to ca. $1.3 \mathrm{Ma}$; Emilian, 1.3-1.2 Ma (ages are approximate). The Sicilian base is at about 1.1-1.2 Ma, whereas the top has not yet been defined; it should occur shortly after the end of the Jaramillo Subchron.

\section{ACKNOWLEDGMENTS}

I thank Prof. F. Proto Decima (University of Padova) and Dr. G. Palmieri (Agip Mineraria, Milano), who reviewed the manuscript and suggested valuable improvements. Many thanks are due to Dr. Isabella Raffi.(University of Parma) for her most helpful and cooperative attitude in discussions and her generosity in allowing me to use unpublished data. Dr. R. Alinovi, Mr. P. Bacchini, Dr. E. Morlotti, Dr. G. Villa, all from the University of Parma, are also acknowledged for their highly appreciated support and suggestions. Miss Sarah Maxwell Scott revised the English. Scanning electron micrographs were made with the assistence of Mr. C. Bocchi (MASPEC Laboratory, Parma). Financial support was provided by the Italian C.N.R. through Grant 80.000397.05 (Paleopelagos Coordinated Research Group).

\section{REFERENCES}

Arias, C., Bigazzi, G., Bonadonna, F. P., Conti, M. A., Iaccarino, S., Radicati, F., and Rio, D., 1976. Chronostratigraphy of Marco Simone Quarry (Central Italy). Boll. Soc. Geol. It., 95:1657-1679.

Bandy, O. L., and Wilcoxon, J. A., 1970. The Plio-Pleistocene boundary, Italy and California. Geol. Soc. Am. Bull., 81:29-39.

Berggren, W. A., and Van Couvering, J., 1974. The late Neogene. Biostratigraphy, geochronology and paleoclimatology of the last 15 million years in marine and continental sequences. Palaeogeogr. Palaeoclimatol. Palaeoecol., 16:1-216.

Borsetti, A. M., and Cati, F., 1972. Il nannoplancton calcareo vivente nel Tirreno centromeridionale. G. Geol., ser. 2a:395-452.

Boudreaux, J. E., and Hay, W. W., 1969. Calcareous nannoplankton and biostratigraphy of the late Pliocene-Pleistocene sediments in Submarex cores. Rev. Esp. Micropaleontol., 1:249-292.

Bowen, D. Q., 1978. Quaternary Geology. A Stratigraphic Framework for Multidisciplinary Work: New York (Pergamon Press).

Bukry, D., 1973a. Low-latitude coccolith biostratigraphic zonation. In Edgar, N. T., Saunders, J. B., et al., Init. Repts. DSDP, 15: Washington (U.S. Govt. Printing Office), 685-704.

1973b. Coccolith stratigraphy - eastern equatorial Pacific, Leg 16 Deep Sea Drilling Project. In van Andel, T. H., Heath, G. R., et al., Init. Repts. DSDP, 16: Washington (U.S. Govt. Printing Office), 653-712.

, 1975. Coccolith and silicoflagellate stratigraphy, northwestern Pacific Ocean, Deep Sea Drilling Project, Leg 32. In Larson, R. L., Moberly, R., et al., Init. Repts. DSDP, 32: Washington (U.S. Govt. Printing Office), 677-702.

Cita, M. B., 1973. Biostratigraphy and chronostratigraphy. In Ryan, W. B. F., Hsü, K. J., et al., Init. Repts. DSDP, 13, Pt. 2: Washington (U.S. Govt. Printing Office), 1343-1379.

Cita, M. B., and Gartner, S., Jr., 1973. The stratotype Zanclean. Foraminiferal and nannofossil biostratigraphy. Riv. Ital. Paleontol. 79:503-558.

Clocchiatti, M., 1971. Sur l'existence de coccospheres portant des coccolithes de Gephyrocapsa oceanica et de Emiliania huxleyi (Coccolithophorides). C. R. Hebd. Seances Acad. Sci. Ser. D, 273: 318-321.

Colalongo, M. L., Elmi, C., and Sartoni, S., 1974. Stratotypes of the Pliocene and Santerno River section. Mem. B.R.G.M., V Congres Neog. Mediter., Lyon, 2:603-624.

Colalongo, M. L., Pasini, G., and Sartoni, S., 1980. Remarks on the Neogene Quaternary boundary at the Vrica Section. Preprint presented at the $26^{\text {th }}$ Intern. Geol. Congr., section S.08, Paris.

Colalongo, M. L., Rio, D., and Wezel, F. C., in preparation. Calcareous plankton biostratigraphy of D.S.D.P. Site 132 (Tyrrhenian Sea, Western Mediterranean).

Cooke, H. B. S., 1973. Pleistocene chronology: long or short? Quat. Res., 3:206-220.
Deflandre, G., and Fert, C., 1954. Observations sur le Coccolithophoridés actuels et fossiles en microscopie ordinarie et électronique. Ann. Paléont., 40:115-176.

Di Stefano, E., and Rio, D., in press. Biostratigrafia a nannofossili del Siciliano. Ateneo Parmense Acta Nat.

Emiliani, C., Mayeda, T., and Selli, R., 1961. Paleotemperature analysis of the Plio-Pleistocene section at Le Castella, Calabria, southern Italy. Geol. Soc. Am. Bull., 72:679-688.

Gaarder, K. R., 1970. Three new taxa of Coccolithineae. Nytt. Mag. Bot., 17:113-126.

Gartner, S., Jr., 1972. Late Pleistocene calcareous nannofossils in the Caribbean and their interoceanic correlation. Palaeogeogr. $\mathrm{Pa}$ laeoclimat. Palaeoecol., 12:169-191.

1977a. Nannofossil biostratigraphy of the Monte Narbone Formation at the type-locality of the Rossellian superstage. Riv. Ital. Paleont., 83:179-190.

1977b. Calcareous nannofossil biostratigraphy and revised zonation of the Pleistocene. Mar. Micropaleont., 2:1-25.

Hamilton, N., 1979. A paleomagnetic study of sediments from Site 397, Northwest African Continental Margin. In von Rad, U., Ryan, W. B. F., et al., Init. Repts. DSDP, 47, Pt. 1: Washington (U.S. Govt. Printing Office).

Haq, B. U., and Berggren, W. A., 1978. Late Neogene calcareous plankton biochronology of the Rio Grande Rise (South Atlantic Ocean). J. Paleontol., 52:1167-1194.

Haq, B. U., Berggren, W. A., and Van Couvering, J. A., 1977. Corrected age of the Pliocene/Pleistocene Boundary. Nature, 269: 483-488.

Hay, W. W., 1977. Calcareous nannofossils. In Ramsay, A. T. S. (Ed.), Oceanic Micropaleontol., 2:1055-1200.

Hay, W. W., and Beaudry, F. M., 1973. Calcareous nannofossils: Leg 15, Deep Sea Drilling Project. In Edgar, N. T., Saunders, J. B., et al., Init. Repts. DSDP, 15: Washington (U.S. Govt. Printing Office), 625-684.

Hay, W. W., Mohler, H. P., Roth, P. H., Schmidt, R. R., and Boudreaux, J. E., 1967. Calcareous nannoplankton zonation of the Cenozoic of the Gulf Coast and Caribbean-Antillean area and transoceanic correlation. Trans. Gulf Coast Ass. Geol. Soc., 17: 438-480.

Hedberg, H. D., 1976. See International Subcommission on Stratigraphic Classification.

1978. Stratotypes and an international geochronologic scale. In Cohee, G. V., Glaessner, M. F., and Hedberg, H. D. (Eds.), Contribution to the Geological Time Scale: AAPG Studies in Geology, 6:33-38.

Kamptner, E., 1943. Zur Revision der Coccolithineen-Spezies Pontosphaera huxleyi LOHM. Anz. Akad. Wiss Wien, Math.-Naturwiss. Kl., 80:43-49.

1963. Coccolithineen-Skelettreste aus Tiefseeablagerungen des Pazifischen Ozeans. Ann. Naturh. Mus. Wien, 66:139-204.

Kukla, G. J., 1975. Loess stratigraphy of central Europe. In Butzer, K. W., and Le Isaac, G. (Eds.), After the Australopithecinus: The Hague (Molton Publishers), pp. 100-187.

Iaccarino, S., 1967. Les foraminifères du stratotype du Tabianien (Pliocène inférieur) de Tabiano Bagni (Parma). Men. Soc. Ital. Nat., 15:165-180.

International Subcommission on Stratigraphic Classification of IUGS Commission on Stratigraphy, 1976. In Hedberg, H. D. (Ed.), International Stratigraphic Guide: New York (John Wiley and Sons).

Lohman, W. H., and Ellis, C. H., 1981. A new species and new fossil occurrences of calcareous nannoplancton in the Eastern Mediterranean. J. Paleont., 55:389-394.

McIntyre, A.. 1970. Gephyrocapsa protohuxleyi sp. n.: a possible phyletic link and index fossil for the Pleistocene. Deep Sea Res., $17: 187-190$.

McIntyre, A., and Bé, A. W. H., 1967. Modern Coccolithophoridae of the Atlantic Ocean. Placoliths and cyrtholiths. Deep Sea Res., 14:561-597.

McIntyre, A., Bé, A. W. H., and Preikstas, R., 1967. Coccoliths and the Pliocene/Pleistocene boundary. Prog. Oceanogr., 4:3-25.

Markali, J., and Paasche, E., 1955. On two species of Umbellosphaera, a new marine coccolithophorid genus. Nytt. Mag. Bot., 44: 95-100. 
Martini, E., 1971. Standard Tertiary and Quaternary calcareous nannoplankton zonation. Proc. Second Plankt. Conf. Roma 1970, 2: 739-785.

Mazzei, R., Raffi, I., Rio, D., Hamilton, N., and Cita, M. B., 1979. Calibration of late Neogene calcareous plankton datum planes with the paleomagnetic record of Site 397 and correlation with Moroccan and Mediterranean sections. In von Rad, U., Ryan, W., B. F., et al., Init. Repts. DSDP, 47, Pt. 1: Washington (U.S. Govt. Printing Office), 375-389.

Nikiforova, K. V., and Alekseev, M. N., 1978. Geological Correlations. I.G.C.P., Spec. Issue, 41:87-88.

Nishida, S., 1971. Nannofossils from Japan IV. Calcareous nannoplankton from the Tônohama group, Shikoku, Southwest Japan. Trans. Proc. Palaeont. Soc. Jpn., 83:143-161.

Okada, H., and Honjo, S., 1973. The distribution of oceanic coccolithophorids in the Pacific. Deep Sea Res., 20:355-374.

Okada, H., and McIntyre, A., 1977. Modern coccolithophores of the Pacific and North Atlantic Oceans. Micropaleontology, 23:1-55.

Parke, M., 1971. The production of calcareoous elements by benthic Algae belonging to the class Haptophyceae (Chrysophyta). Proc. Second Plankt. Conf. Roma, 2:929-937.

Parke, M., and Adams, I., 1960. The motile (Crystallolithus hyalinus Gaarder and Markali) and non-motile phases in the life history of Coccolithus pelagicus (Wallich) Schiller. J. Mar. Biol. Assoc. U. K., 39:263-274.

Pelosio, G., Raffi, S., and Rio, D., 1980. The Plio-Pleistocene boundary controversy. Status in 1979 at the light of International Stratigraphic Guide. In Petrucci, F., and Cavazzina, R. (Eds.), Volume Dedicato a Sergio Venzo: Parma (Grafiche STEP), pp. 131-140.

Perch-Nielsen, K., 1971. Durchsicht Tertiarer Coccolithen. Proc. Second Plankt. Conf. Roma, 2:939-979.

Pirini-Radrizzani, C., and Valleri, G., 1977. New data on calcareous nannofossils from the Pliocene of the Tyrrhenian Basin Site 132 DSDP, Leg 13. Riv. Ital. Paleontol., 83:897-924.

Proto Decima, F., 1974. Leg 27 calcareous nannoplankton. In Veevers, J. J., Heirtzler, J. R., et al., Init. Repts. DSDP, 27: Washington (U.S. Govt. Printing Office), 589-622.

Proto Decima, F., and Masotti, C. (in press). The Genus Gephyrocapsa (Coccolithophorales) in the Plio-Pleistocene of the Timor Trough. Mem. Sc. Geol.

Raffi, I., and Rio, D., 1979. Calcareous nannofossil biostratigraphy of DSDP Site 132-Leg 13 (Tyrrhenian Sea-Western Mediterrranean). Riv. Ital. Paleontol., 85:127-172.

1980. Biostratigrafia a nannofossili, biocronologia e cronostratigrafia della serie del Torrente Tiepido (Subappennino Emiliano, Provincia di Modena). Ateneo Parmense Acta Nat., 16: 19-31.

, in press a. Il nannoplancton calcareo dello stratotipo del Tabianiano (Tabiano Bagni-Parma). In Petronio, C. (Ed.), Paleontologia Stratigrafica ed Evoluzione (Vol. 1): Rome (CNR).

, in press b. Nannoplancton calcareo del Pliocene superiore-

Pleistocene inferiore della serie del Fiume Santerno. In Petronio, C. (Ed.), Paleontologia Stratigrafica ed Evoluzione (Vol. 1): Rome (CNR).

, in press c. Nuove osservazioni sulla distribuzione del nannoplancton calcareo nella serie di Le Castella (Calabria). In Petro- nio, C. (Ed.), Paleontologia Stratigrafica ed Evoluzione (Vol. 1): Rome (CNR).

Rio, D., 1974. Remarks on late Pliocene-early Pleistocene calcareous nannofossil stratigraphy in Italy. Ateneo Parmense Acta Nat., 10:409-449.

Rio, D., Mazzei, R., and Palmieri, G., 1976. The stratigraphic position of the Mediterranean upper Miocene Evaporites, based on nannofossils. Mem. Soc. Geol. It., 16:261-276.

Rio, D., Ruggieri, G., and Sprovieri, R., in preparation. Globorotalia truncatulinoides plexus in Mediterranean fossil record.

Rögl, F., 1974. The evolution of the Globorotalia truncatulinoides and Globorotalia crassaformis group in the Pliocene and Pleistocene of the Timor Trough, DSDP Leg 27, Site 362. In Veevers, J. J., Heirtzler, J. R., et al., Init. Repts. DSDP, 27: Washington (U.S. Govt. Printing Office), 743-767.

Ruggieri, G., Buccheri, G., Greco, A., and Sprovieri, R., 1976. Un affioramento di Siciliano nel quadro della revisione della stratigrafia del Pleistocene inferiore. Boll.Soc. Geol. It., 94:889-914.

Ruggieri, G., and Sprovieri, R., 1977. A revision of Italian Pleistocene stratigraphy. Geol. Rom, 16:131-139.

Sachs, J. B., and Skinner, H. C., 1973. Late Pliocene-early Pleistocene nannofossil stratigraphy in the north central Gulf Coast area. Proc. Symp. Calc. Nannofossils Gulf Coast Sect. SEPM, Houston, pp. 94-125.

Selli, R., 1971. Calabrian. G. Geol., 37:55-64.

Selli, R., Accorsi, C. A., Bandini Mazzanti, M., et al., 1977. The Vrica Section (Calabria, Italy): a potential Neogene/Quaternary boundary stratotype. G. Geol., 42:181-204.

Smith, L. A., 1969. Pleistocene discoasters at the stratotype of the Calabrian stage (Santa Maria di Catanzaro) and Le Castella, Italy. Trans. Gulf Coast Assoc. Geol. Soc., 19:579-583.

Sprovieri, R., 1978. I foraminiferi bentonici della sezione plio-pleistocenica di Capo Rossello (Agrigento, Sicilia). Boll. Soc. Paleontol. It., 17:68-97.

Sprovieri, R., Ruggieri, G., and Unti, M., in press. Globorotalia truncatulinoides excelsa N. subsp., foraminifero planctonico guida per il Pleistocene inferiore. Boll. Soc. Geol. It.

Stradner, H., 1973. Catalogue of calcareous nannoplankton from sediments of Neogene age in the eastern North Atlantic and Mediterranean Sea. In Ryan, W. B. F., Hsu, K. J., et al., Init. Repts. $D S D P$, 13, Pt. 2: Washington (U.S. Govt. Printing Office), 1137-1199.

Thunell, R. C., 1979. Pliocene-Pleistocene paleotemperatures and paleosalinity history of the Mediterranean Sea. Results from D.S.D.P. Sites 125 and 132. Mar. Micropaleontol., 4:173-187.

Van Eysinga, F. W. B., 1975. Geological Time Table: Amsterdam (Elsevier).

Venzo, S., 1975. New data on the proposed Plio-Pleistocene boundary type-section of Le Castella (Calabria, Italy). I. Remarks on the stratigraphic and paleontological sequence Ateneo Parmense Acta Nat., 11:423-447.

Watabe, N., and Wilbur, K. M., 1966. Effects of temperature on growth calcification and coccolith form in Coccolithus huxleyi (Coccolithineae). Limnol. Oceanogr., 11:567-575. 


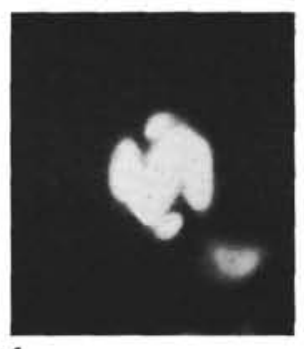

1

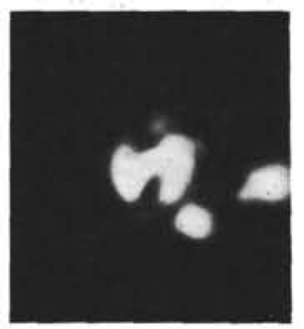

5

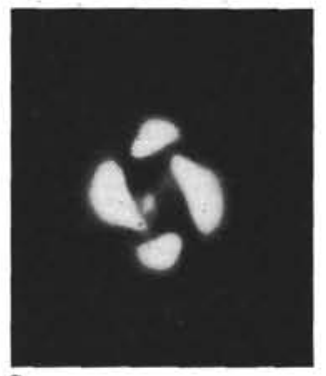

9

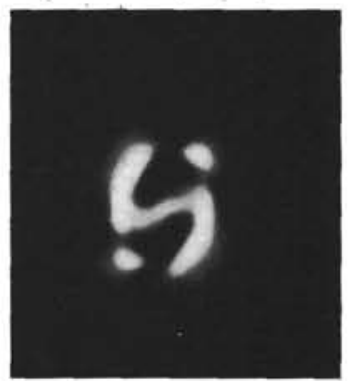

13

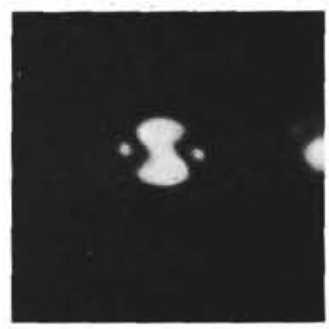

2

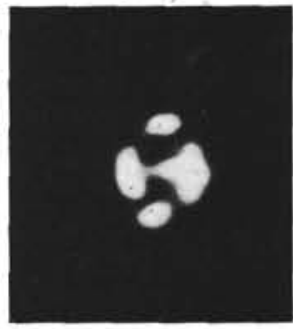

6
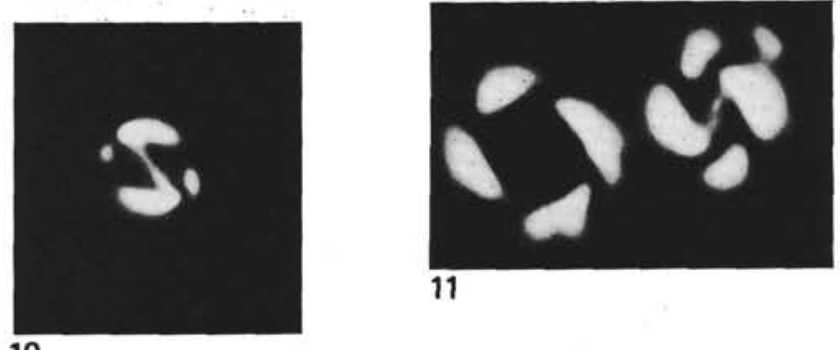

11

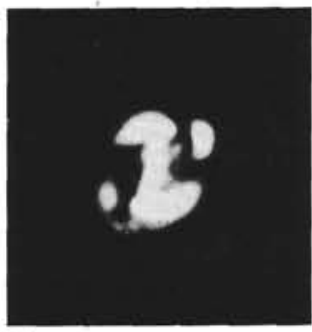

7

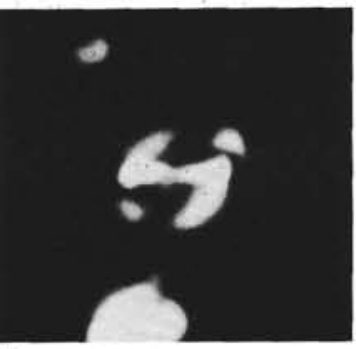

3

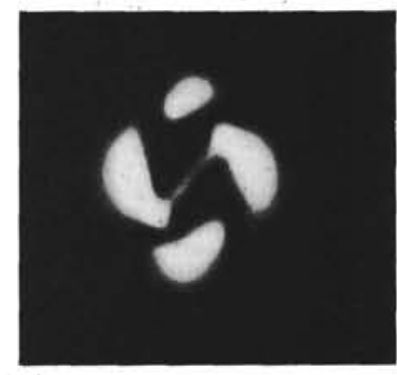

14

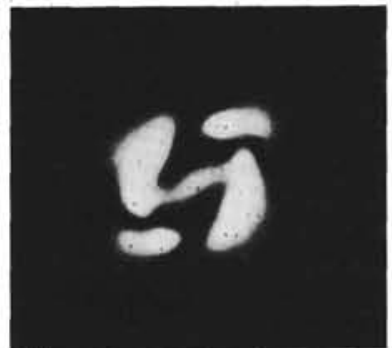

15
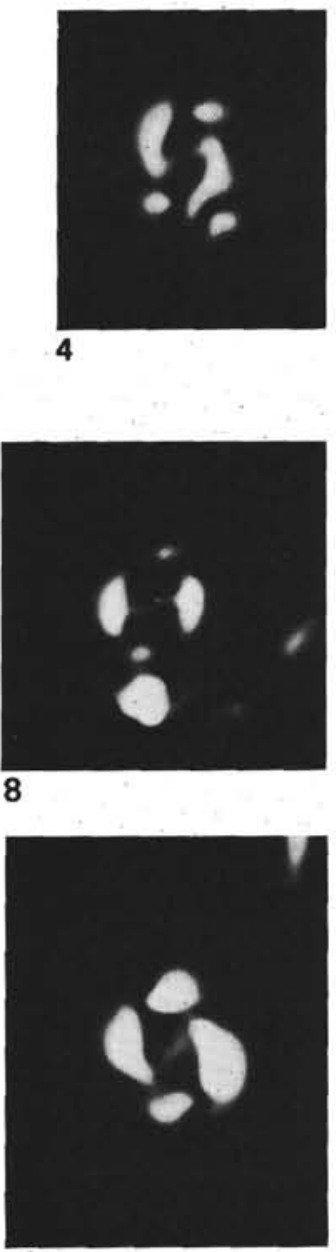

8

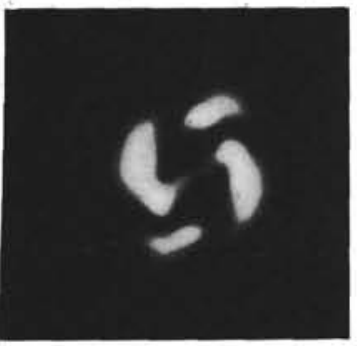

16

Plate 1. Light micrographs. 1-6. Small Gephyrocapsa of the middle Pliocene interval, cross-polarized light, ca. $\times 4000$. (1-4) Sample 503B-18-3, $40-41 \mathrm{~cm}$. $(5,6)$ Sample 503B-18-1, 110-111 cm. 7,8,10. Small Gephyrocapsa of the upper Pliocene interval, cross-polarized light, ca. $\times 4000$. $(7,8)$ Sample 502B-13-2, 124-125 cm. (10) Sample 502B-11-1, 50-51 cm. 9,11-16. Gephyrocapsa oceanica s.l., cross-polarized light, ca. $\times 4000$. $(9,11,12)$ Sample 502B-11-1, 50-51 cm. (13) Sample 502B-9-2, 124-125 cm. $(14,16)$ "Marker bed" of Le Castella section. (15) Sample 132-3-3, $130-131 \mathrm{~cm}$. 

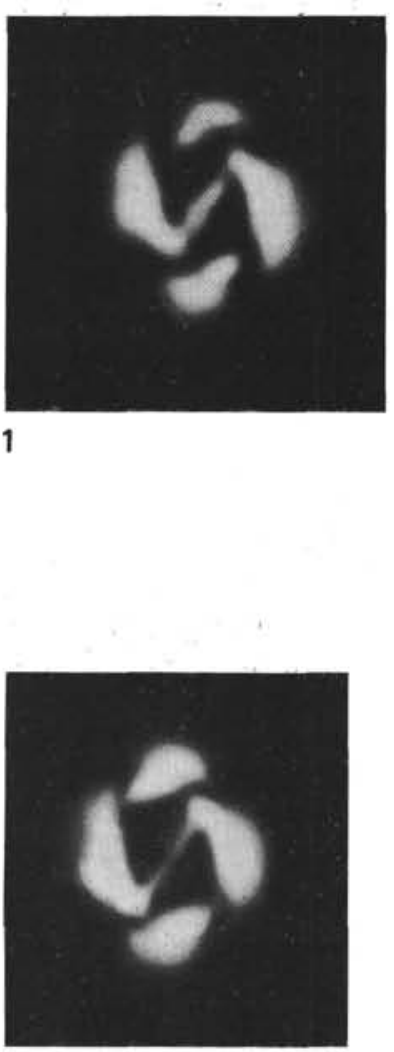

5
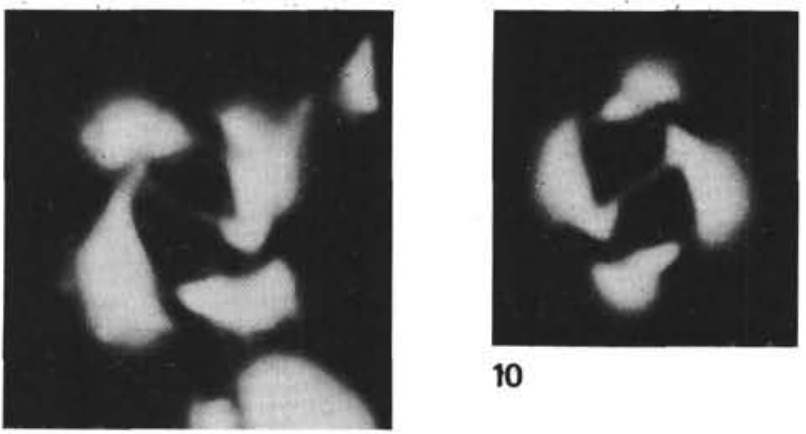

10

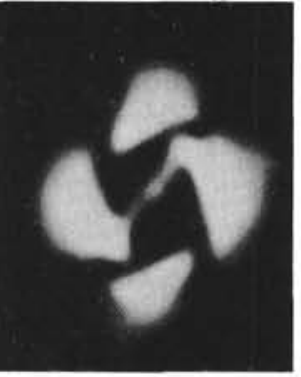

6

9

Plate 2. Light micrographs. 1-3. Gephyrocapsa oceanica s.1., cross-polarized light, ca. $\times 4000$. "Marker bed" of Le Castella section. (4-12). Large Gephyrocapsa of the lower Pleistocene interval, cross-polarized light, ca. $\times 4000$. (4) Sample 262-32-1, 87-88 cm. (5) Vrica section, $239 \mathrm{~m}$. $(6,7)$ Sample 125-3-1, 119-121 cm. (8) Sample 132-6-3, 116-117 cm. (9-11) Sample 125-3-3, 15-17 cm. (10) Sample 132-7-2, 12-13 cm. (12) Sample $132-6-4,90-91 \mathrm{~cm}$.

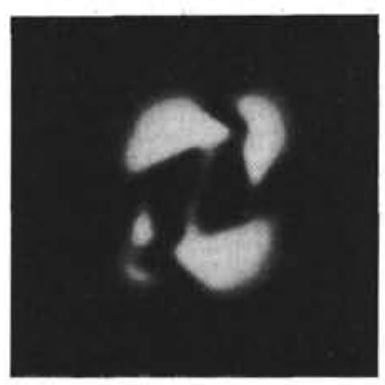

3
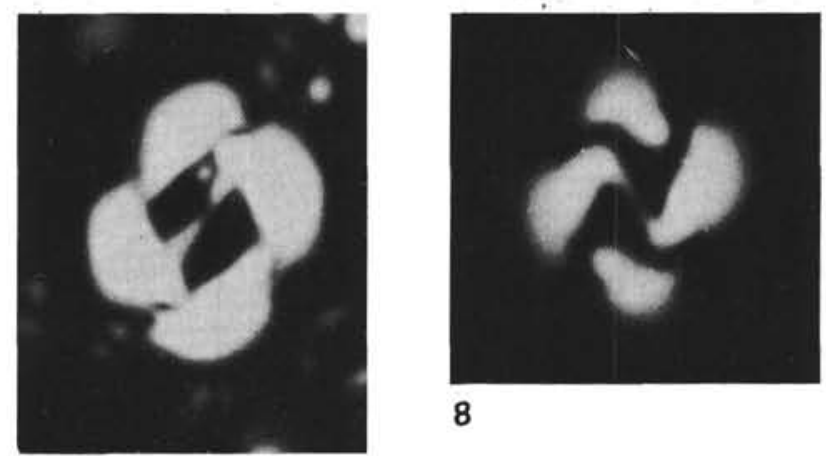

8

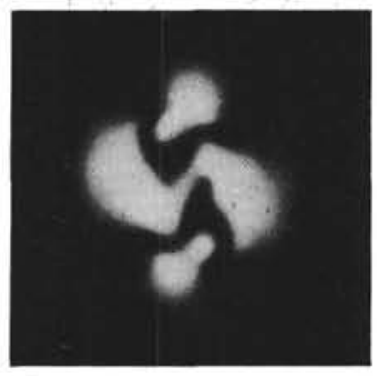

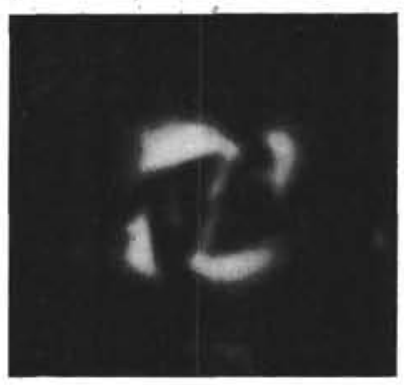

4

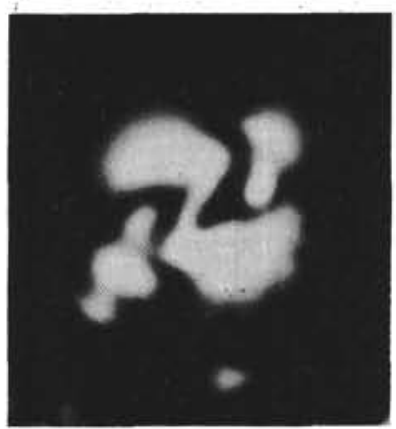

11
12

7 


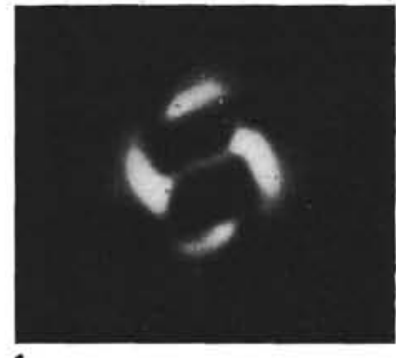

1

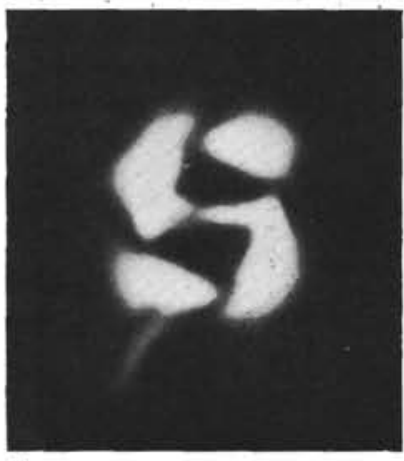

5

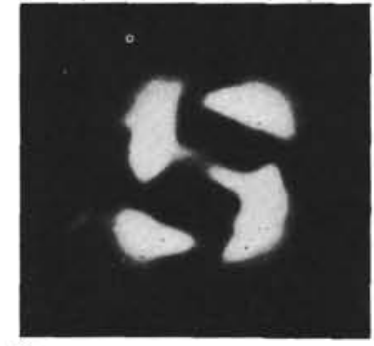

8

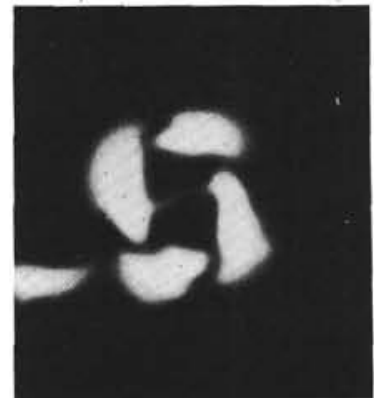

2

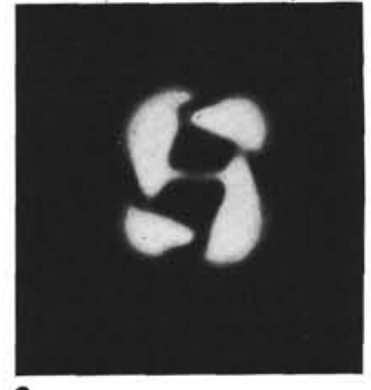

3

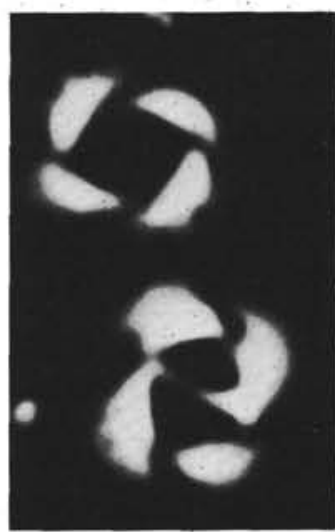

4

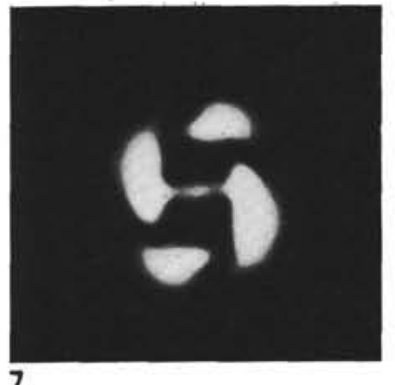

7

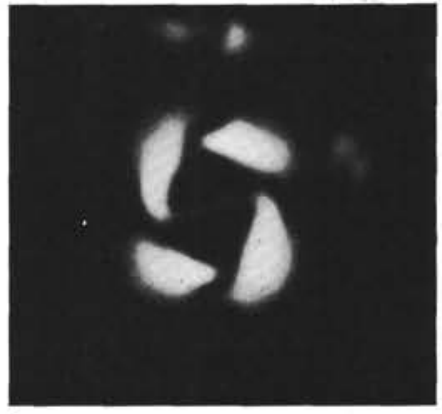

6

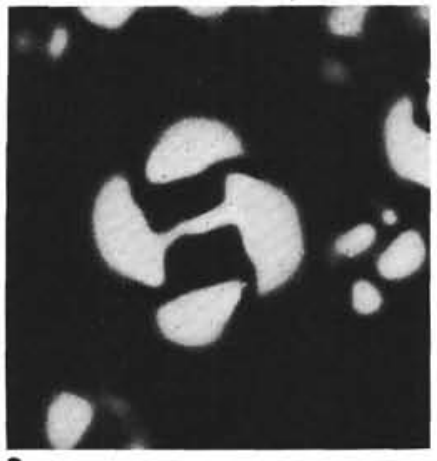

9

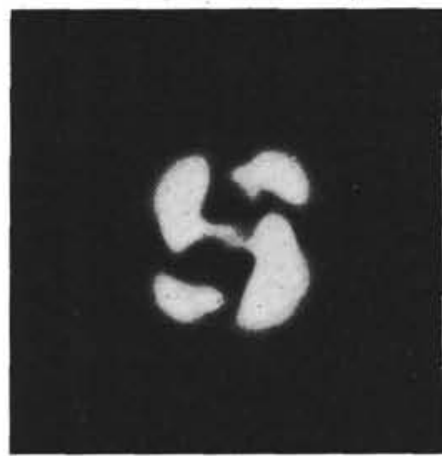

10

Plate 3. Light micrographs. 1-8. Gephyrocapsa oceanica s.1. with the bridge parallel or near parallel to the short axis, cross-polarized light, ca. $\times 4000$. (1) Sample 262-29-1, 90-91 cm. (2,3) Sample V26-40, $620 \mathrm{~cm}$. (4) Sample V26-40, $590 \mathrm{~cm}$. (5) Sample 502B-5-1, 124-125 cm. (6) Sample $502 \mathrm{~B}-4-3,124-125 \mathrm{~cm}$. (7,8) Sample 502B-4-1, 70-71 cm. (9) Sample 502B-3-3, 70-71 cm. (10) Sample 132-4-2, 47-48 cm. 

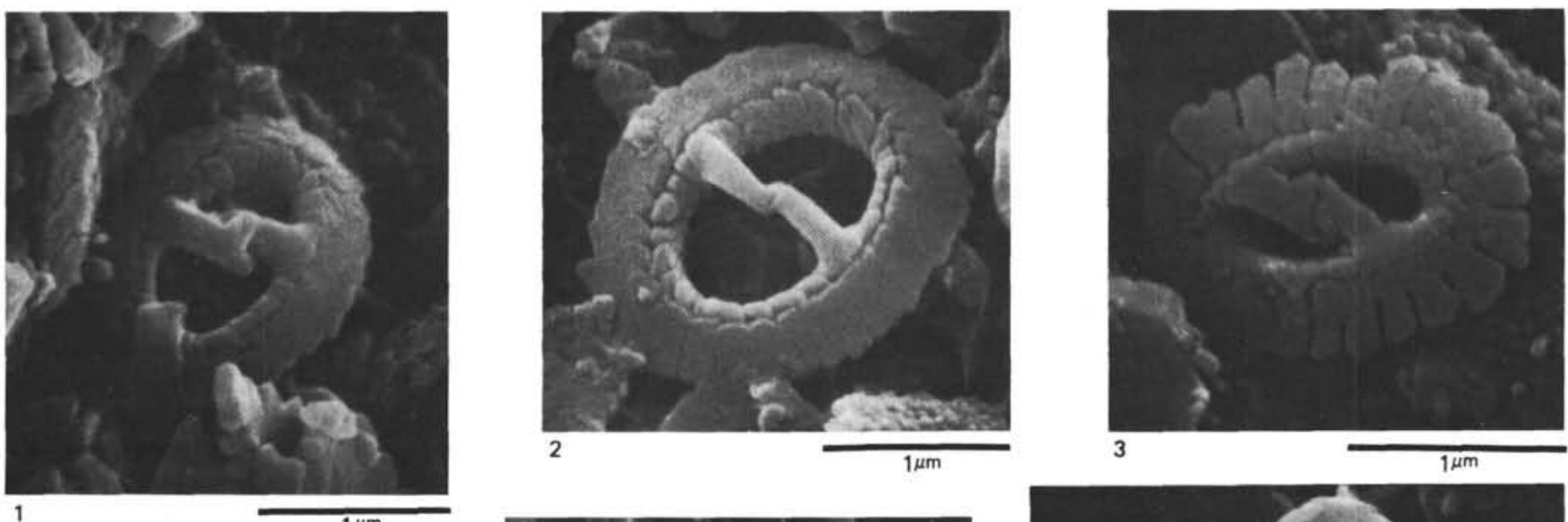

1
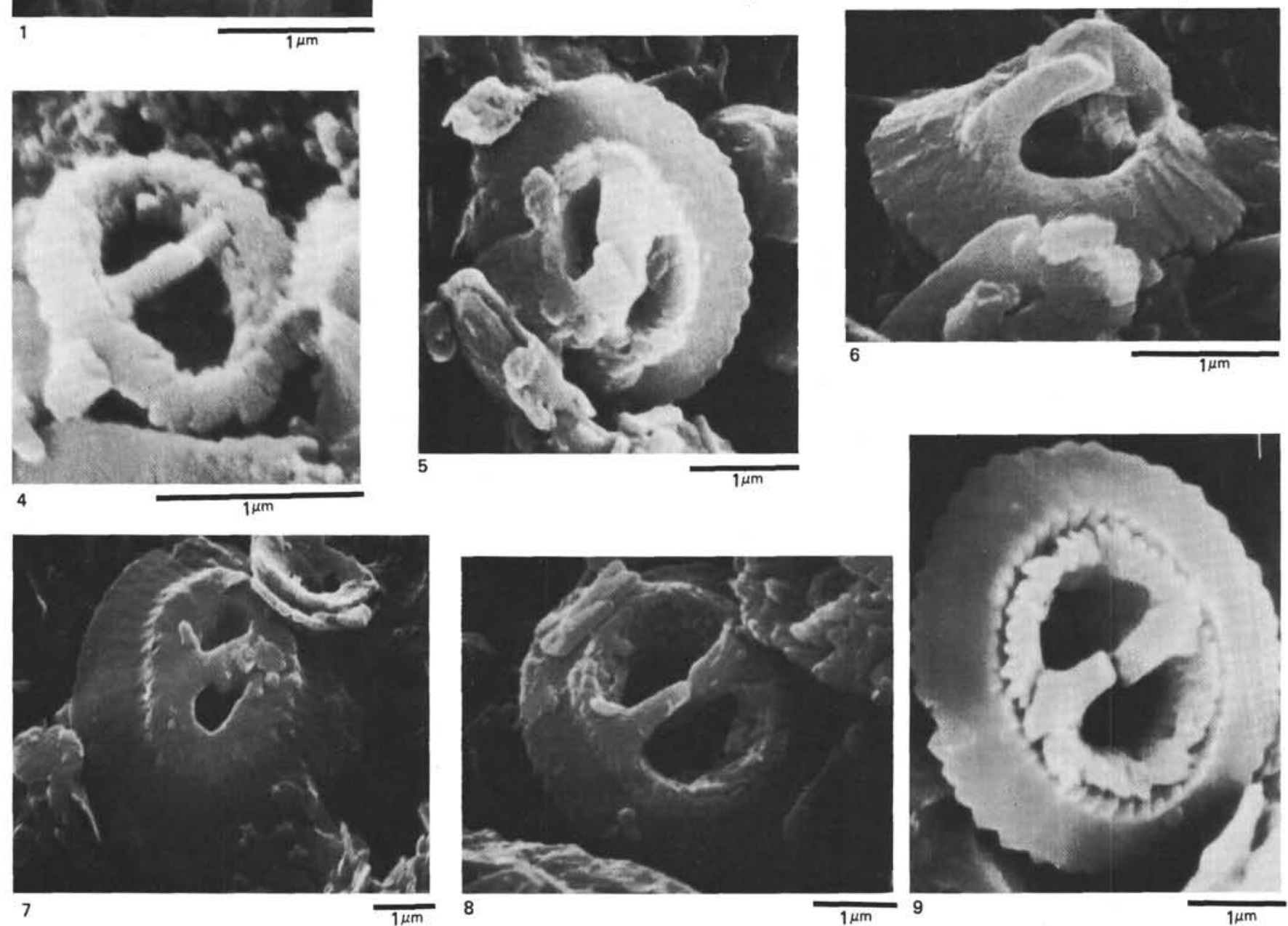

Plate 4. Scanning electron micrographs. 1-4. Small Gephyrocapsa of the middle Pliocene interval, SEM micrographs, Sample 503B-18-1, 110-111 $\mathrm{cm}$. 5. Small Gephyrocapsa of the upper Pliocene interval, SEM, Sample 502B-11-3, 124-125 cm. 6. Small Gephyrocapsa, SEM, Sample 502B-7-3, 50-51 cm. 7. Large Gephyrocapsa, SEM, Sample 502B-7-3, 50-51 cm. 8,9. Gephyrocapsa oceanica s.l. with the bridge parallel or near parallel to the short axis, SEM. (8) Sample V26-40, $590 \mathrm{~cm}$. (9) Ficarazzi sequence, 11.90-12 meters. 